\title{
NĚKOLIK POZNÁMEK K MATERIÁLOVÉ STRUKTUŘE A MECHANICKÝM VLASTNOSTEM SEGMENTŮ LAMELOVÝCH ZBROJÍ
}

\author{
JOSEF HLOŽEK - JARMILA SAVKOVÁ - JOSEF VOLÁK
}

\begin{abstract}
Abstrakt: Přestože lamelové zbroje, tzv. brigantiny, patři k pokročilým typům středověkých zbrojí, postrádáme u většiny dochovaných exemplárư, torz či ojedinélých nálezů lamel informace o jejich materiálových vlastnostech, způsobu zpracováni a kvalitě. Výsledky nově provedených metalografických analýz prozatím nepublikovaných železných lamel pocházejícich z areálů hradů Přimdy, Landštejna a Nového Herštejna vnáší více světla do problematiky konstrukce tohoto typu zbroje a zejména pak spektra materiálù použitých k jeho výrobè.
\end{abstract}

Kličová slova: brigantina - zbroj-středověk - hrad-metalografická analýza.

\section{Some Notes on the Material Structure and Mechanical Properties of Lamellar Armour Plates}

\begin{abstract}
Although lamellar armour known as brigandine counts among the advanced types of medieval armour, the majority of preserved specimens, their fragments and sporadic finds of lamellae do not provide information about its material properties, the manner of manufacture and quality. The results of the latest metallographic analyses of unpublished iron lamellae from the Přimda, Landštejn and Nový Herštejn castles help elucidate the construction of this type of armour and, in particular, the spectrum of materials used for its production.
\end{abstract}

Key words: brigandine - armour - Middle Ages - castle - metallographic analysis.

\section{Úvod}

Pozůstalost prof. PhDr. Tomáše Durdíka, DrSc., představuje obsáhlý soubor artefaktů reprezentující jednu z etap české kastellologie (Durdík 2007). V rámci její inventarizace a postupného zpracování byla provedena metalografická analýza 18 exemplář lamel pocházejících z několika zbrojí nalezených v areálech hradů Přimdy (Durdík 2006; 2007), Landštejna (např. Durdík-Havlová 1990) a Nového Herštejna (Durdík-Procházka 1978; 2002; Procházka 1998; Jánský 2004). Fragmenty středověkých zbrojí patří ve srovnání s nálezy ostatních kovových předmětů k obecně méně četným archeologickým nálezům. Na mnohých lokalitách, kde by bylo možné jejich přítomnost očekávat, však nebyly jejich fragmenty doposud zachyceny (k této problematice např. Durdík 1982; Belcredi 1989; Krajíc 2003; Frolík-Musil 2015). Tato skutečnost může být ovlivněna řadou faktorů: mírou poznání jednotlivých lokalit, způsobem jejich zániku (Procházka 1998, 222; Žákovský 2009, 438), spektrem archeologických transformací, kterými byly formovány (k této problematice např. Neustupný 1986, 527-531; 2007, 46-64), a v neposlední řadě také mírou poškození těchto lokalit v důsledku nelegálního působení majitelů detektorů kovů (namátkou Čižmář 2006; Kuna 2006; Smrž 2006; Baierl 2010). Železné segmenty související se segmentovou nebo kombinovanou zbrojí jsou známy nejen z obecně vyššího sociálního prostředí (např. Durdík 1984, 14). S nálezy lamel se setkáváme v různých částech hradních organismů v místech souvisejících s více či méně rozsáhlými konflikty (např. Thordeman 1940; 1940a; 2001; Procházka 1998, 222; Marek 2008), ale také v prostředí dalších sídelních aglomerací různého charakteru (pro oblast českých zemí např. Nekuda 1985, 138-139; Měchurová 1997, LII:1; Krajíc 2003, 130; Kouřil 2009; Knápek 2011). Tato skutečnost koresponduje s řadou dochovaných právních omezení týkajících se měštanů a jejich práva nosit zbraň. Na vlastnictví ani nošení zbroje se žádná taková dochovaná omezení nevztahovala (Wagner-Durdík-Drobná 1956, 53-54).

Většinu dokladů brigantin či kombinovaných zbrojí (např. Žákovský 2009) z archeologických kontextů nebo sbírek různého charakteru představují ojedinělé kovové lamely, jejich nevelké kolekce, zlomky jednotlivých exempláŕů nebo větši či menší části zbrojí. Zejména s ohledem na velmi různorodý stav dochování lamel, které tvořily součást obou typů zbrojí, a jejich tvarovou variabilitu zůstávala řada exemplářů $\mathrm{v}$ depozitáŕích sbírkotvorných organizací či v různých 
sbírkách po dlouhou dobu nerozpoznána (např. Durdík 1983, 14). Na tuto skutečnost upozornil také prozatím poslední provedený soupis nálezů lamel segmentových zbrojí na našem území (Zitová 2013). Některé z kovových lamel dochovaných v rámci archeologických situací nebo prezentovaných $\mathrm{v}$ různých expozicích však nemusely vždy souviset jen s brigantinami. $\mathrm{V}$ této souvislosti je nutné upozornit také na skutečnost, že se železné či obecně kovové, např. mosazné, lamely uplatnily také při výrobě železných rukavic či bot (např. Thordeman 2001, 118). V př́ípadě tzv. kombinovaných zbrojí byly lamely různého tvaru užívány k ochraně zádových partií a boků, kde mohly být nahrazeny také kroužkovou brní, a v neposlední řadě také k ochraně slabin a partií pod úrovní pasu v podobě sukničky či šorců (Žákovský 2009, 416-419, 434 s odkazy na další literaturu). I přes poměrně pokročilé vědomosti o konstrukci, vlastnostech i míře použití různých, nejen lamelových, typů zbrojí prozatím - až na výjimky (např. Williams 1999; Starley 2005; Hošek 2003, 85; Williams 2003; 2009) - postrádáme podrobnější informace o materiálových vlastnostech jejich kovových částí.

S ohledem na soubor kladených otázek se v největší stručnosti dotkneme pouze několika souvislostí spojených s vývojem lamelové a kombinované zbroje. Ikonografické prameny, především monumentální figurální plastika (Wagner-Durdík-Drobná 1956, část II tab. 2; Žákovský 2009, 413 s přehledem literatury), ale také desková a knižní malba z území západní a střední Evropy ilustrují stoupající oblibu a význam lamelové zbroje od 13. století a zejména pak v průběhu 14. století, kdy se tento typ zbroje dále vyvíjí a stává běžnější, avšak nákladnou součástí hmotné kultury. I v průběhu 15. a dále pak v 16. století si tento typ zbroje v podobě severoitalských corazzin, vyrobených z velkého množství drobných lichoběžníkovitých lamel, udržel značnou oblibu (např. Thordeman 1940; 1940a; 2001; Müller 1957, 93; Blackmore 1965, 18; Blair 1979, 58; Klučina-Romaňák 1983, 155-158; Beneš 1991; 1992, 11; Kouřil-Prix-Wihoda 2000, 560; Scalini 2003). Současně s rozvojem brigantin však dochází již v průběhu 40. let 14. století (např. Gamber 1953; Žákovský 2009, 414-418) v důsledku zvětšování a stmelování použitých lamel ke vzniku kombinovaných zbrojí sestávajících z celoplátového kyrysu kombinovaného s dalšími, především lamelami tvořenými segmenty chránícími břišní a zádové partie, boky a též partie pod úrovní pasu. Další vývoj se od závěru 14. století ubírá směrem k celoplátovým kyrysům kryjícím hrud' i břišní partie. Tyto kyrysy byly doplněny o další ochranu tvořenou plátovými segmenty kryjícími části zádových partií, lamelami různého charakteru či kroužkovou brní. I u těchto zbrojí se uplatnilo, podobně jako u lamelové zbroje, potažení jejich povrchu textilií (Žákovský 2009, 421 s přehledem evropské literatury a širších souvislostí). V následujícím období vývoj směřoval již k celoplátovým zbrojím.

\section{Metalografický rozbor a charakteristika souboru hodnocených lamel}

Soubor železných lamel byl podroben základní metalografické analýze s cílem vytvoření přehledu materiálů použitých k výrobě brigantin a jejich vlastností. Při hodnocení jednotlivých lamel byl přednostně odebírán materiál z jejich okraje tak, aby byla možná zpětná rekonstrukce jednotlivých exemplářů a nedošlo k jejich znehodnocení pro další výstavní účely (viz tab. 1 a 2). Záměrně pak nebyly do souboru hodnocených lamel zařazeny exempláře pocházející z požárem zaniklého manského domu hradu Křivoklátu (např. Durdík 1988; 1995). Intenzivní zánikový požár mohl významnou měrou ovlivnit strukturní vlastnosti použitého materiálu. Př́ikladem může být krojidlo pluhu nalezené v požárem zaniklé usedlosti středověké vesnice Sloupek na Rokycansku. Materiálové vlastnosti krojidla byly ovlivněny nejen přímým působením vysokého žáru, ale také velmi pozvolným chladnutím v požárovém horizontu. Tento proces nejspíše zaprríčinil vznik Widmannstättenovy struktury na povrchu krojidla (Hložek-Savková-Vařeka v př́ípravě).

Odebíraný materiál byl dělen na přesné pomaloběžné pile Buehler IsoMet LS s použitím diamantového kotouče o tloušt'ce $0,3 \mathrm{~mm}$. Výbrusy vzorků byly připraveny běžnými postupy, zahrnujícími zalití za studena, broušení za mokra, leštění diamantovými pastami a leptání Nitalem. Mikrostruktura byla dokumentována pomocí optických mikroskopů Nikon Epiphot 200 a Nikon SMZ800 a 3D optického mikroskopu Hirox KH8700. Identifikace prvkového složení 
jednotlivých strukturních částí separovaných vzorků bylo provedeno na skenovacím mikroskopu FEI Quanta 200 ve spojení s EDS detektorem EDAX s využitím plošné a bodové analýzy. Hodnocení mikrotvrdosti strukturních částí dle Vickerse bylo prováděno na tvrdoměru Buehler 2100 při zatížení 2,942 N ( $\left.\mathrm{HV}_{0,3}\right)$.

Předmětem zájmu pak bylo nejen materiálové složení lamel, ale také místa jejich spojů pomocí nýtů vykazujících různé vlastnosti i povrchové úpravy, jež mají mimo jiné i vliv na estetické kvality zbroje.

Prvkové složeníl povrchové úpravy některých nýtů bylo provedeno metodou XRF. Pro analýzu byl použit přenosný spektrometr XL3t 980 GOLDD vyrobený firmou Niton (USA). Spektrometr je vybaven rentgenkou (X-ray generator) $50 \mathrm{kV} / 2,0 \mathrm{~W}$ se stř́ibrnou anodou. Jednotlivá měření probíhala $\mathrm{v}$ základním továrním nastavení přístroje $\mathrm{v}$ režimu ,general metals“ $\mathrm{s}$ nastavením kolimátoru (collimator) v režimu „small spot“" o průměru $3 \mathrm{~mm}$ a celkovou dobou měření 45 sekund. Spektrometr byl upevněn v pracovním stolku „Thermo Scientific Smart Stand“, který

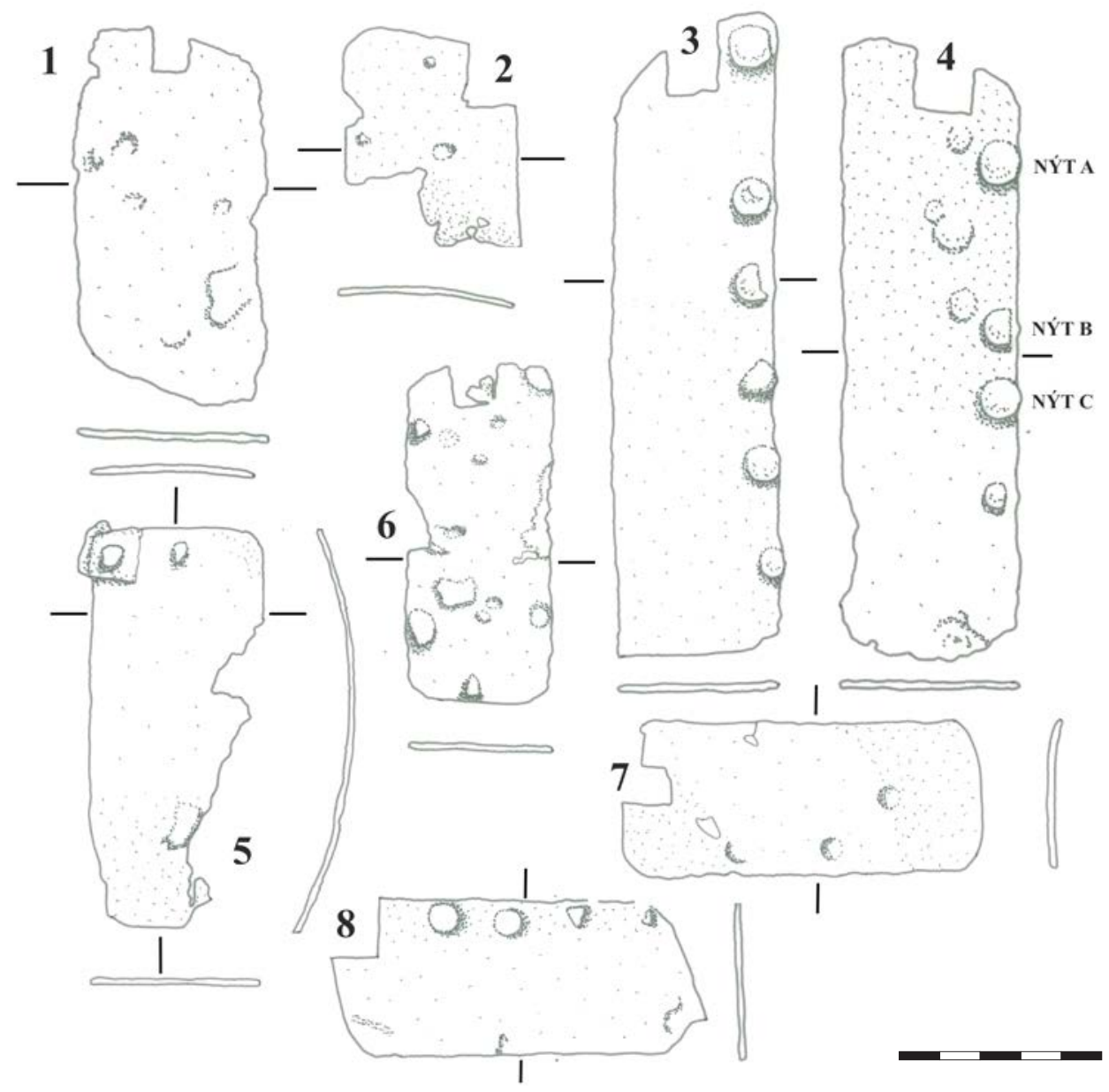

Tab. 1. Kolekce hodnocených brigantin. Čísla jednotlivých lamel odpovídají číslování lamel v textu. Na lamelách jsou patrná místa po odběru vzorků materiálu. Kresba H. Krasanovská.

Taf. 1. Kollektion der ausgewerteten Brigantinen. Die Ziffern der einzelnen Lamellen entsprechen der Nummerierung der Lamellen im Text. An den Lamellen sind die Entnahmestellen der Materialproben zu erkennen. Zeichnung H. Krasanovská.

1 Za provedení měření děkujeme PhDr. Janu Maříkovi, Ph.D., z Archeologického ústavu AV ČR, Praha, v. v. i. 

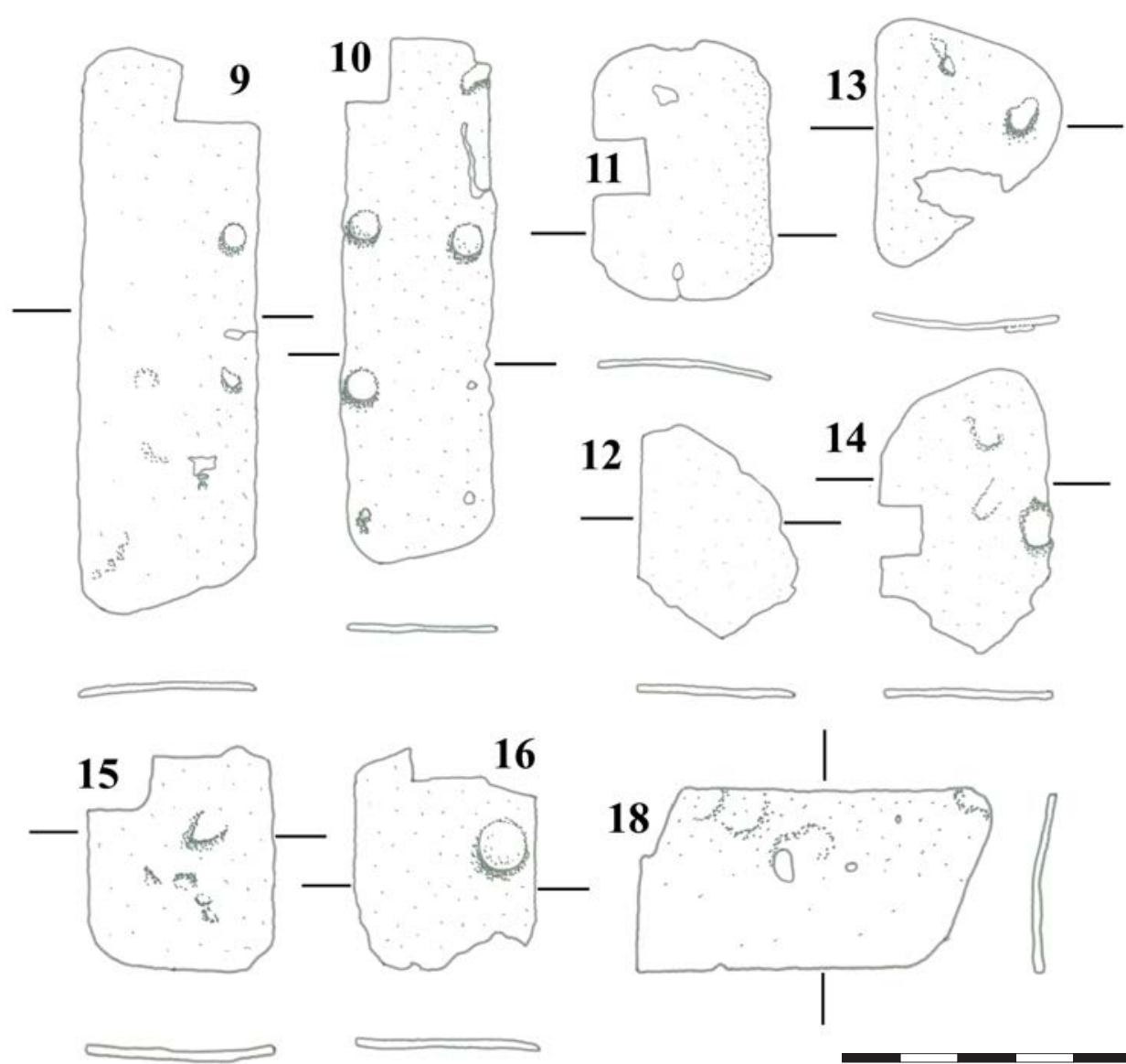

Tab. 2. Kolekce hodnocených brigantin. Čísla jednotlivých lamel odpovídají číslování lamel v textu. Na lamelách jsou patrná místa po odběru vzorků materiálu. Kresba H. Krasanovská.

Taf. 2. Kollektion der ausgewerteten Brigantinen. Die Ziffern der einzelnen Lamellen entsprechen der Nummerierung der Lamellen im Text. An den Lamellen sind die Entnahmestellen der Materialproben zu erkennen. Zeichnung H. Krasanovská.

zajištoval stabilní vzdálenost jednotlivých vzorků od přístroje. Povrch měřených hlav nýtů vykazujících povrchovou úpravu byl očištěn při standardní konzervaci. Další zvláštní úpravy povrchu nebyly před měřením prováděny.

Odolnost hodnocených lamel s dostatečně dochovaným kovovým jádrem byla testována prostřednictvím Small Punch Testu. Jde o relativně novou metodu vhodnou ke stanovování materiálových charakteristik (mez pevnosti, kluzu, deformace atd.) zejména u materiálů, které jsou k dispozici v omezeném množství. Podstatou metody je protlačování disku průměru $8 \mathrm{~mm}$, nejčastěji tloušt'ky $0,5 \mathrm{~mm} \pm 0,005$, kuličkou o průměru $2,5 \mathrm{~mm}$. Výsledkem testu je stanovení vztahu síla vs. deformace. Vzorky byly vyrobeny na drátořezu bez tepelného ovlivnění. Následně byly podrobeny metalografickému broušení na finální rozměr. Poté byly realizovány jednotlivé testy (obr. 14).

\section{Popis lamel a jejich metalografické hodnocení}

Hodnocený soubor obsahuje 18 exemplářů železných lamel různého tvaru s různým počtem dochovaných nýtů. I přes stabilní a pevný povrch hodnocených lamel nebylo ve všech prŕípadech dochováno jejich kovové jádro, nebo jeho velmi špatná míra dochování neumožňovala metalografické vyhodnocení. 
Lamela č. 1 (tab. 1, obr. 1)

Lokalita/rok: Přimda ${ }^{2}$

Rozměry a hmotnost: $73 \times 38 \mathrm{~mm}$; tloušt'ka $2 \mathrm{~mm}$; prohnutí $11 \mathrm{~mm}$; hmotnost $22 \mathrm{~g}$

Popis: Jednostranně zkosená lamela se zaoblenými rohy, při okraji jeden nýt bez hlavy.

Metalografický rozbor: Lamela je složena ze dvou materiálů o přibližně stejném podílu. Přechodová oblast se nachází zhruba $\mathrm{v}$ polovině tloušt'ky lamely. Materiál v horní části je tvořen martenzitickými jehlicemi, vměstkovitost je relativně nízká, nitkovitého tvaru ve směru kolmém na tváření, s výjimkou vkovaného zoxidovaného pásu; spodní část lamely je tvořena hrubozrnným feritem s malým podílem vměstků. Korozní napadení okraje lamely je relativně výrazné. Výhradně v okolí nýtu byly na povrchu lamely zaznamenány stopy cínu. Tvrdost: martenzitická část $-440 \mathrm{HV}_{0,3}$, feritická část $-185 \mathrm{HV}_{0,3}$.

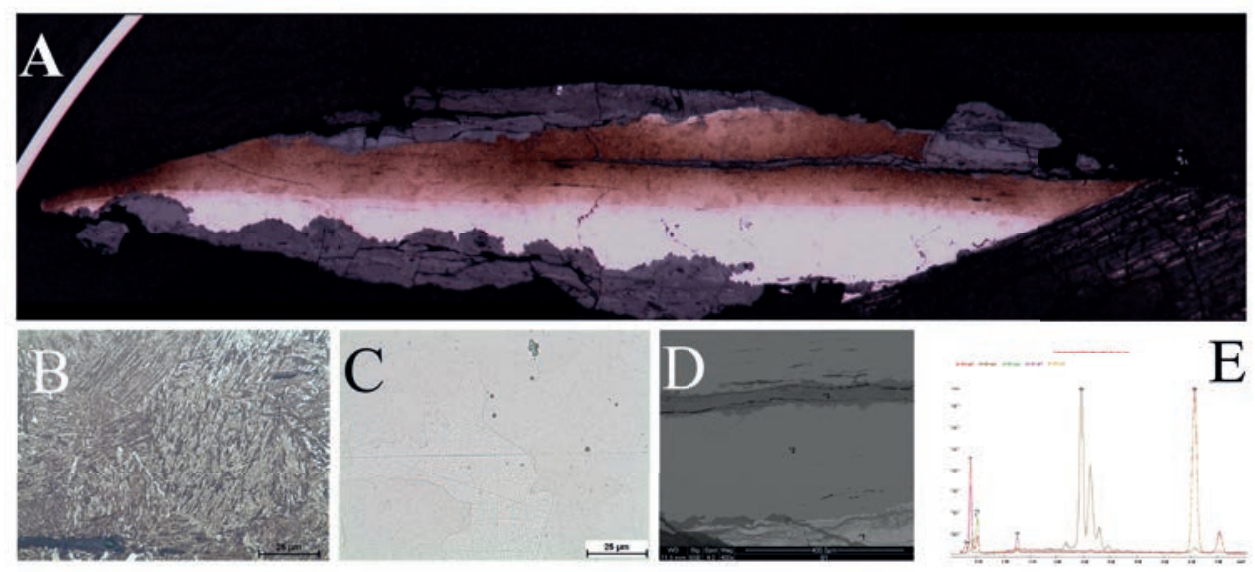

Obr. 1. Lamela 1. A - přehledový snímek př́ičného řezu lamelou, metalografický výbrus, leptáno Nitalem; B - martenzitická struktura (horní část lamely); C - hrubozrnný ferit (dolní část lamely); D - analyzovaná oblast EDX v materiálovém kontrastu; E - EDX analýza složení - cín na povrchu lamely. Foto J. Savková.

Abb. 1. Lamelle 1. A - Übersichtsaufnahme des Lamellenquerschnitts, metallographischer Schliff, mit Nital geätzt; B - martensitische Struktur (oberer Lamellenteil); C - grobkörniges Ferrit (unterer Lamellenteil); D - Analysierter EDX-Bereich im Materialkontrast; E - EDX-Analyse der Zusammensetzung - Zinn auf der Lamellenoberfläche. Foto J. Savková.

\section{Lamela č. 2 (tab. 1, obr. 2)}

Lokalita/rok: Nový Herštejn 1977

Rozměry a hmotnost: šířka $40 \mathrm{~mm}$; tloušt'ka $1,8 \mathrm{~mm}$; prohnutí není možné hodnotit kvůli částečné deformaci lamely; hmotnost $11 \mathrm{~g}$

Popis: Neúplná pravděpodobně obdélná lamela se zaoblenými rohy, při okrajích dva nýty bez hlavy.

Metalografický rozbor: Povrch lamely vykazuje pokročilý stupeň koroze. Kovové jádro lamely je tvořeno hrubozrnným feritem bez přítomnosti vměstků. Tvrdost: $100 \mathrm{HV}_{0,3}$.
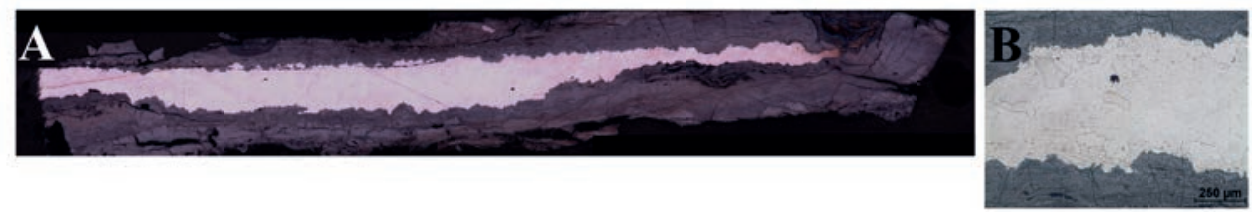

Obr. 2. Lamela 2. A - přehledový snímek přičného řezu lamelou, metalografický výbrus, leptáno Nitalem; B - hrubozrnný ferit. Foto J. Savková.

Abb. 2. Lamelle 2. A - Übersichtsaufnahme des Lamellenquerschnitts, metallographischer Schliff, mit Nital geätzt; B-grobkörniges Ferrit. Foto J. Savková.

2 Bez uvedení data nálezu. 
Lamela č. 3 (tab. 1, obr. 3)

Lokalita/rok: Landštejn 1977

Rozměry a hmotnost: $150 \times 36 \mathrm{~mm}$; tloušt'ka $1,5 \mathrm{~mm}$; prohnutí $17 \mathrm{~mm}$; hmotnost $50 \mathrm{~g}$

Popis: Jednostranně zkosená lamela se zaoblenými rohy, při okraji šest nýtů s hlavou o průměru $10-13 \mathrm{~mm}$. Jeden nýt $\mathrm{v}$ řadě patrně chybí.

Metalografický rozbor: Mikrostruktura lamely je tvořena dvěma oblastmi - středovým pásem s feriticko-perlitickou strukturou a okraji tvořenými hrubozrnným feritem. Celkově lamela vykazuje vyšší vměstkovitost podélného i kulovitého tvaru. Nýt byl tvořen hrubozrnným feritem. Tvrdost: lamela - 214-240 $\mathrm{HV}_{0,3}$, nýt $-133 \mathrm{HV}_{0,3}$.

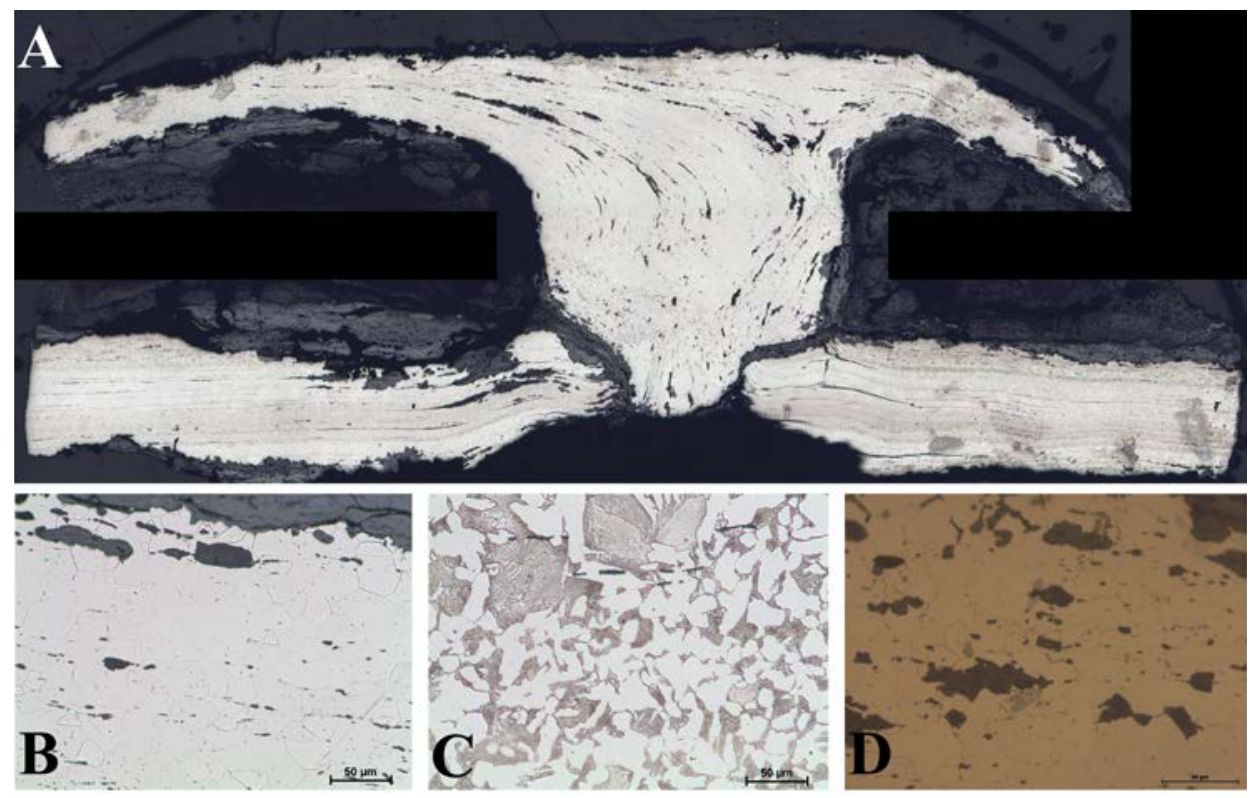

Obr. 3. Lamela 3. A - přehledový snímek přičného řezu lamelou, metalografický výbrus, leptáno Nitalem; B - hrubozrnný ferit (lamela); C - feriticko-perlitická struktura (středový pás lamely); D - hrubozrnný ferit (nýt). Foto J. Savková.

Abb. 3. Lamelle 3. A - Übersichtsaufnahme des Lamellenquerschnitts, metallographischer Schliff, mit Nital geätzt; B - grobkörniges Ferrit (Lamelle); C - ferritisch-perlitische Struktur (Mittelstreifen der Lamelle); D - grobkörniges Ferrit (Niete). Foto J. Savková.

\section{Lamela č. 4 (tab. 1, obr. 4)}

Lokalita/rok: Landštejn 1977

Rozměry a hmotnost: $128 \times 37 \mathrm{~mm}$; tloušt'ka $1,5 \mathrm{~mm}$; prohnutí není možné hodnotit kvůli deformaci; hmotnost $46 \mathrm{~g}$

Popis: Jednostranně zkosená lamela se zaoblenými rohy, při okraji jeden nýt s odlomenou hlavou a čtyři nýty s hlavou potaženou vrstvou tvořenou slitinou mědi o průměru $10-11 \mathrm{~mm}$. Jeden nýt byl odebrán jako součást metalografického vzorku.

Metalografický rozbor: Lamela je tvořen dvěma materiály - ve středních partiích hmoty lamely byl zaznamenán jemnozrnný ferit, na povrchu ferit s vyloučeným perlitem na hranicích zrn. Oba materiály jsou odděleny korozní vrstvou. Zachovalý a v podobě vzorku odebraný nýt je tvořen hrubozrnným feritem s hlavou pokrytou cínovým bronzem. Hlava nýtu je finálně pokryta vrstvou tvořenou slitinou mědi, resp. mosazí. XRF měření bylo provedeno u všech tří finálně upravených nýtů na lamele: Nýt 1 - Cu 77,18 hm. \%; Zn 17,77 hm. \%; Sn 1,64 hm. \%; Ti 1,08 hm. \%; ostatní 2,33 hm. \%; Nýt 2 - Cu 77,40 hm. \%; Zn 17,14 hm. \%; Sn 2,18 hm. \%; ostatní 3,28 hm. \%; Nýt 3 - Cu 76,64 hm. \%; Zn 16,8 hm. \%; Sn 3,58 hm. \%; Pb 0,87 hm. \%; ostatní 2,11 hm. \%. Tvrdost: lamela $-118 \mathrm{HV}_{0,3} ;$ nýt $-213 \mathrm{HV}_{0,3}$. 


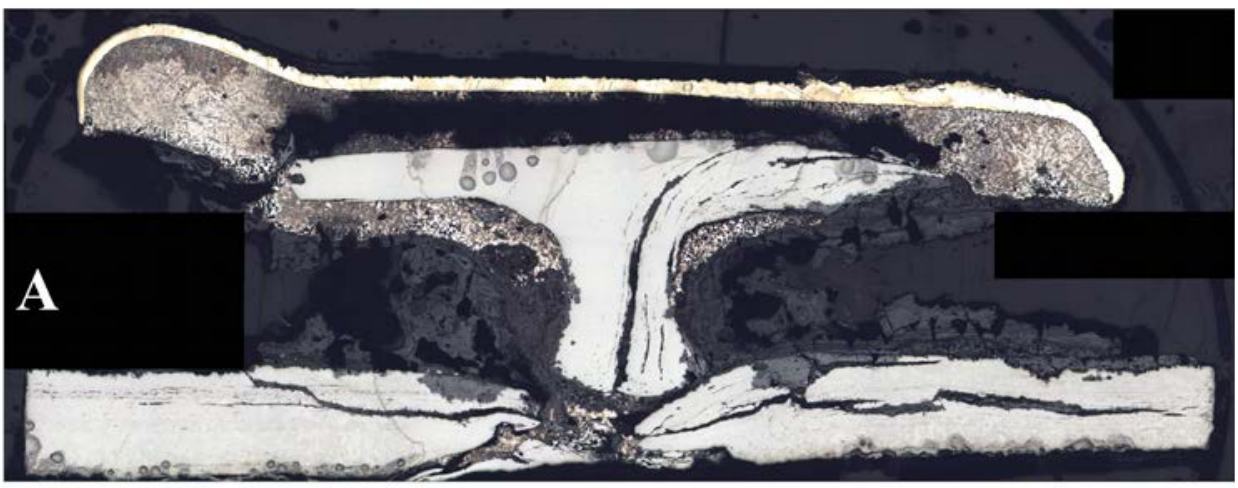

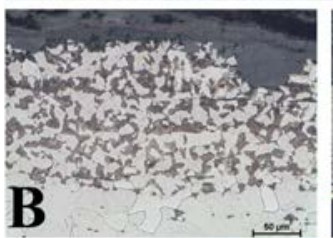

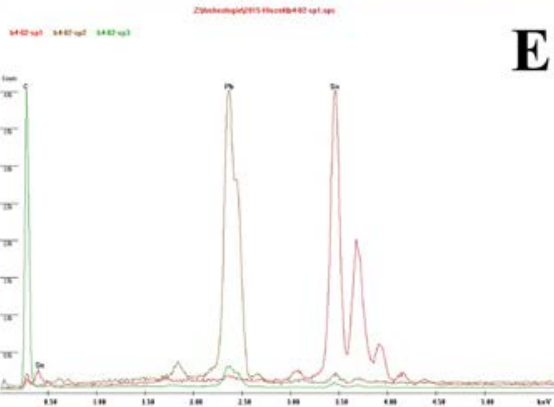

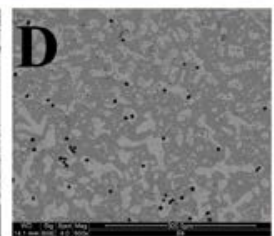

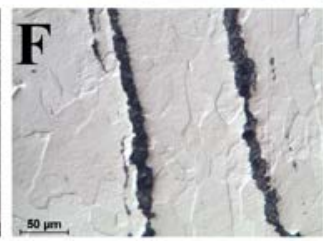

Obr. 4. Lamela 4. A - přehledový snímek příčného řezu lamelou, metalografický výbrus, leptáno Nitalem; B - feriticko-perlitická struktura; C - hrubozrnný ferit; D - analyzovaná oblast EDX v materiálovém kontrastu; E - EDX analýza složení materiálu na povrchu hlavy nýtu - cín a olovo; F - nýt - hrubozrnný ferit. Foto J. Savková.

Abb. 4. Lamelle 4. A - Übersichtsaufnahme des Lamellenquerschnitts, metallographischer Schliff, mit Nital geätzt; B - Ferrit-Perlit-Struktur; C - grobkörniges Ferrit; D - analysierter EDX-Bereich im Materialkontrast; E - EDX-Analyse der Materialzusammensetzung auf der Oberfläche der Nietenköpfe - Zinn und Blei; F - Niete grobkörniges Ferrit. Foto J. Savková.

\section{Lamela č. 5 (tab. 1, obr. 5)}

Lokalita/rok: Landštejn 1977

Rozměry a hmotnost: $98 \times 42 \mathrm{~mm}$; tloušt'ka $1,1 \mathrm{~mm}$; prohnutí $12 \mathrm{~mm}$; hmotnost $26 \mathrm{~g}$

Popis: Obdélná lamela se zaoblenými rohy a třemi nýty velmi poškozenými korozí s hlavou o průměru 7-11 mm. V rohu spojuje nýt dvě lamely. Přinýtovaná lamela dochována pouze v podobě malého, od zbývající části lamely odlomeného fragmentu.

Metalografický rozbor: Materiál lamely je tvořen feritickou ocelí s drobnými vměstky kulovitého až nitkovitého tvaru přibližně v třetině tloušt'ky materiálu lamely. Tvrdost: $160 \mathrm{HV}_{0,3}$.
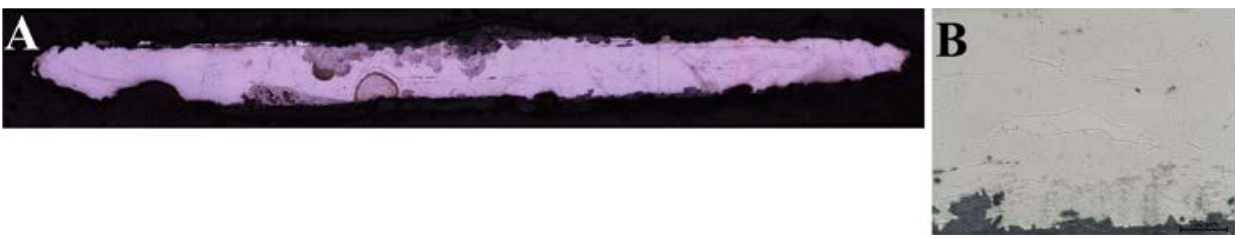

Obr. 5. Lamela 5. A - přehledový snímek př́ičného řezu lamelou, metalografický výbrus, leptáno Nitalem; B - hrubozrnný ferit. Foto J. Savková.

Abb. 5. Lamelle 5. A - Übersichtsaufnahme des Lamellenquerschnitts, metallographischer Schliff, mit Nital geätzt; B - grobkörniges Ferrit. Foto J. Savková. 


\section{Lamela č. 6 (tab. 1, obr. 6)}

Lokalita/rok: Landštejn 1977

Rozměry a hmotnost: $87 \times 30 \mathrm{~mm}$; tloušt'ka $1,1 \mathrm{~mm}$; prohnutí $7 \mathrm{~mm}$ (lamela je mírně deformovaná); hmotnost $26 \mathrm{~g}$

Popis: Obdélná lamela se zaoblenými rohy a se třemi nýty s hlavou o průměru 6-11 $\mathrm{mm}$. Dvě hlavy nýtu potaženy kompaktní vrstvou tvořenou slitinou mědi, resp. mosazí. Na hlavě třetího nýtu je patrné potažení mosazí pouze v podobě špatně zřetelných stop.

Metalografický rozbor: Materiál lamely je ve středové části tvořen hrubozrnným feritem s hrubými nitkovitými vměstky, okrajové části lamely mají martenzitickou strukturu. Odebraný nýt vykazuje feriticko-perlitickou mikrostrukturu, hlava nýtu je pokryta cínovým bronzem. Nýty byly finálně překryty vrstvou tvořenou slitinou mědi, resp. mosazí $(\mathrm{Cu} 73,61 \mathrm{hm}$. \%; Zn 19,99 hm. \%; Sn 1,56 hm. \%; Ti 1,73 hm. \%; ostatní 3,11 hm. \%). Tvrdost: lamela - $156 \mathrm{HV}_{0,3}$, nýt - $192 \mathrm{HV}_{0,3}$, povrch hlavy nýtu - $10 \mathrm{HV}_{0,3}$.
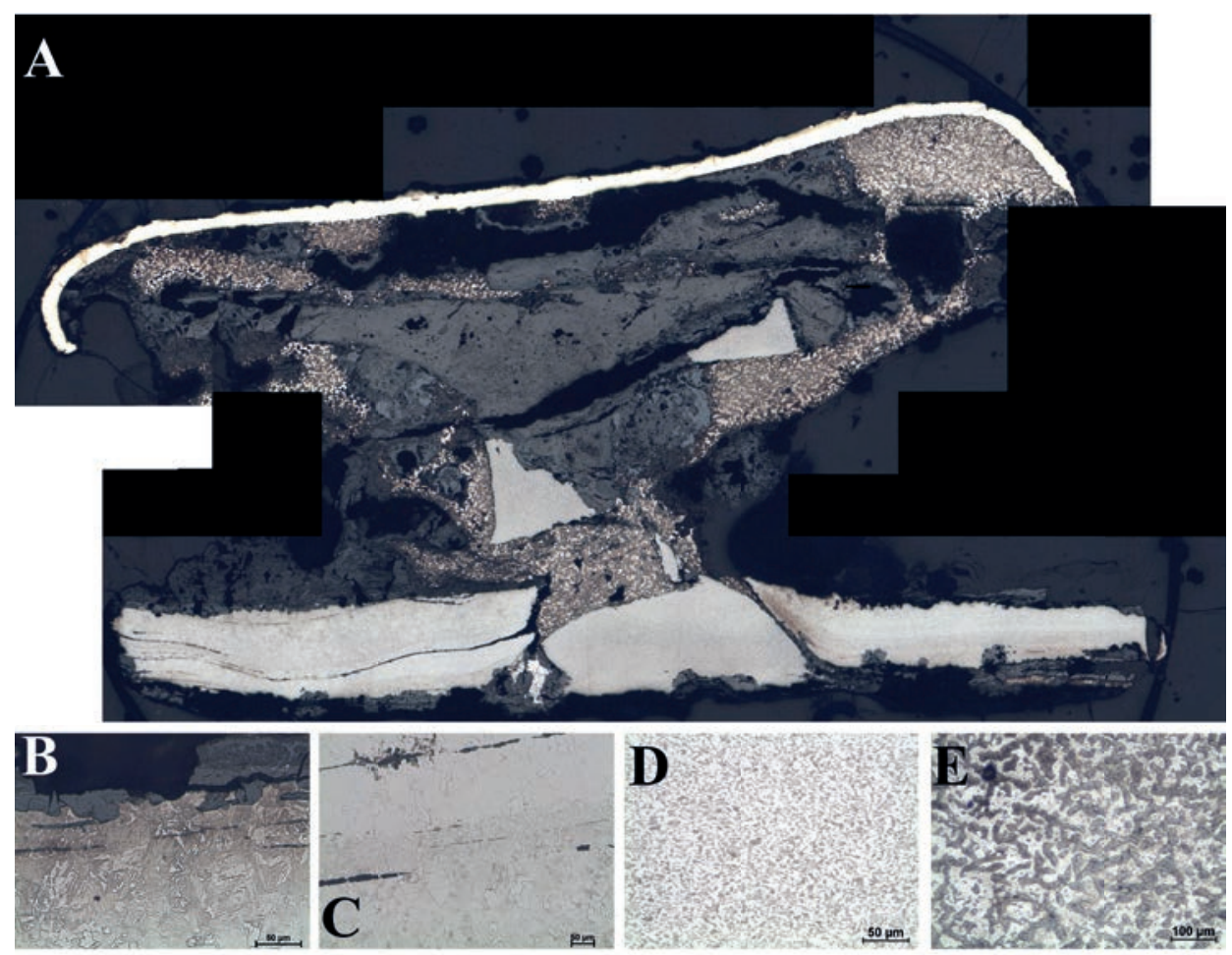

Obr. 6. Lamela 6. A - přehledový snímek přičného řezu lamelou, metalografický výbrus, leptáno Nitalem; B - martenzitická struktura (okraj lamely); C - hrubozrnný ferit (střed lamely); D - jemnozrnná feriticko-perlitická mikrostruktura; $\mathbf{E}$ - cínový bronz na povrchu železného nýtu pod finální úpravou. Foto J. Savková.

Abb. 6. Lamelle 6. A - Übersichtsaufnahme des Lamellenquerschnitts, metallographischer Schliff, mit Nital geätzt; B - martensitische Struktur (Lamellenrand); C - grobkörniges Ferrit (Lamellenmitte); D - feinkörnige ferritisch-perlitische Mikrostruktur; E - Zinnbronze auf der Oberfläche der Eisenniete unter der Endbehandlung. Foto J. Savková.

\section{Lamela č. 7 (tab. 1, obr. 7)}

Lokalita/rok: Landštejn 1977

Rozměry a hmotnost: $92 \times 39 \mathrm{~mm}$; tloušt'ka $1,5 \mathrm{~mm}$; prohnutí $9 \mathrm{~mm}$; hmotnost $22 \mathrm{~g}$ Popis: Obdélná oboustranně prohnutá lamela se zaoblenými rohy patrně s korozí poškozeným otvorem pro nýt pocházející zřejmě z pasové oblasti brigantiny. Jeden nýt, dochovaný při okraji lamely, byl odebrán v rámci vzorku pro metalografickou analýzu. 
Metalografický rozbor: Materiál lamely je tvořen feriticko-perlitickou ocelí, s feritem vyloučeným po kraji perlitu, lamela obsahuje několik hrubších podélných vměstků. Na rozhraní tvořeném okrajem lamely a tělem nýtu je viditelná deformace způsobená mechanickým namáháním. Zachovaný nýt je tvořen hrubozrnným feritem s vysokou vměstkovitostí převážně nitkovitého tvaru. Nýt byl pravděpodobně potažen cínem, dochovaným pouze na styku mezi lamelou a tělem nýtu (viz obr. 1). Tvrdost: lamela $-282 \mathrm{HV}_{0,3}$, nýt $-269 \mathrm{HV}_{0,3}$.

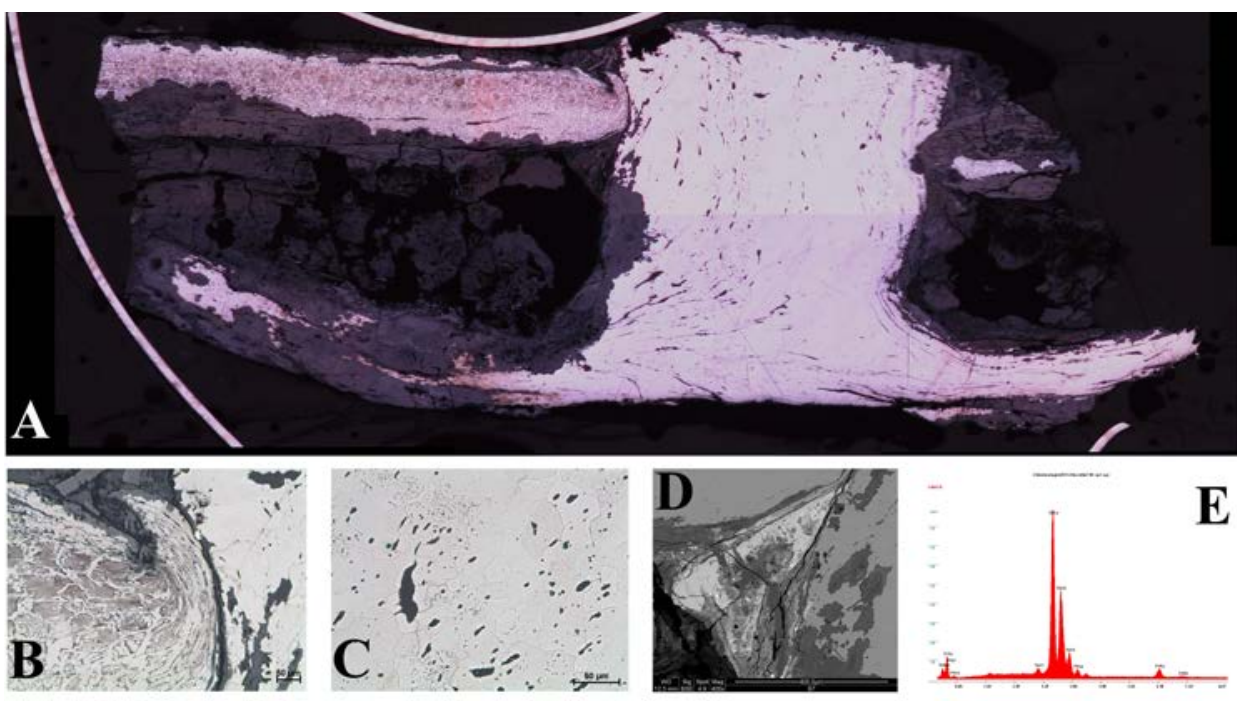

Obr. 7. Lamela 7. A - přehledový snímek příčného řezu lamelou, metalografický výbrus, leptáno Nitalem; B - feriticko-perlitická struktura (lamela); C - hrubozrnný ferit (nýt); D a E-EDX analýza složení - cín na rozhraní lamely a nýtu. Foto J. Savková. Abb. 7. Lamelle 7. A - Übersichtsaufnahme des Lamellenquerschnitts, metallographischer Schliff, mit Nital geätzt; B - ferritisch-perlitische Struktur (Lamelle); C - grobkörniges Ferrit (Niete); D und E - EDX-Analyse der Zusammensetzung Zinn an der Nahtstelle von Lamelle und Niete. Foto J. Savková.

\section{Lamela č. 8 (tab. 1, obr. 8)}

Lokalita/rok: Landštejn 1977

Rozměry a hmotnost: šírka $38 \mathrm{~mm}$; tloušt'ka $1,6 \mathrm{~mm}$; prohnutí $5 \mathrm{~mm}$; hmotnost $25 \mathrm{~g}$

Popis: Lichoběžníková oboustranně prohnutá lamela se zaoblenými rohy a pěti nýty při okraji. Hlavy dvou nýtů o průměru 7,5-8 mm, hlavy dvou nýtů částečně při okrajích odlámané. Jeden nýt odebrán v rámci vzorku.

Metalografický rozbor: Materiál lamely je tvořen hrubozrnným feritem s velkými vměstky kulovitého nebo oválného tvaru. Nýt je výrazně zkorodován, mikrostruktura je feritická s jemným zrnem deformovaným ve směru tváření. Tvrdost: lamela $-176 \mathrm{HV}_{0,3}$, nýt $-306 \mathrm{HV}_{0,3}$.

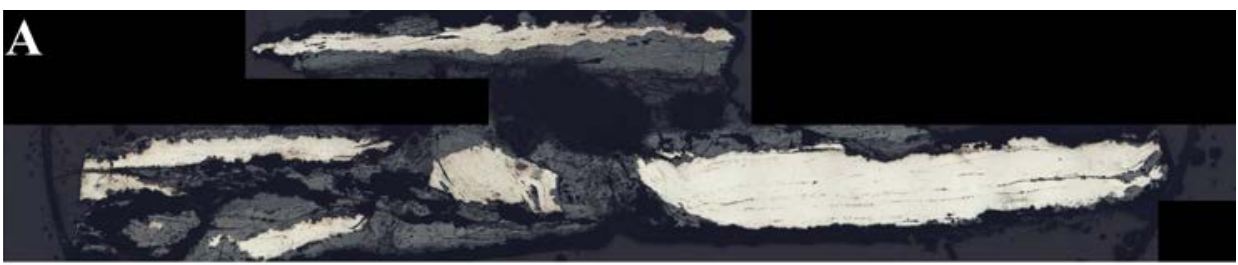

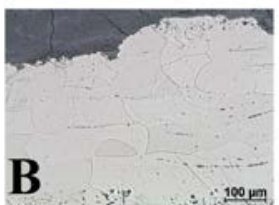

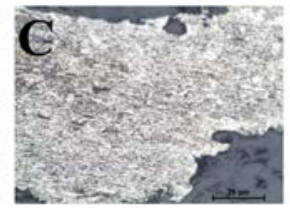

Obr. 8. Lamela 8. A - přehledový snímek příčného řezu lamelou, metalografický výbrus, leptáno Nitalem; B - hrubozrnný ferit (lamela); C - jemnozrnný ferit (nýt). Foto J. Savková.

Abb. 8. Lamelle 8. A - Übersichtsaufnahme des Lamellenquerschnitts, metallographischer Schliff, mit Nital geätzt; B - grobkörniges Ferrit (Lamelle); C - feinkörniges Ferrit (Niete). Foto J. Savková. 


\section{Lamela č. 9 (tab. 2, obr. 9)}

Lokalita/rok: Landštejn 1977

Rozměry a hmotnost: $136 \times 41 \mathrm{~mm}$; tloušt'ka $1,2 \mathrm{~mm}$; prohnutí $18 \mathrm{~mm}$; hmotnost $36 \mathrm{~g}$

Popis: Lichoběžníková lamela se zaoblenými rohy a třemi nýty s hlavou o průměru 7-8 mm. Jeden nýt odebrán jako součást metalografického vzorku.

Metalografický rozbor: Materiál lamely sestává ze dvou materiálů - jemnozrnného a hrubozrnného feritu. Kovářský svar prochází středem lamely. Podél svaru jsou patrné jemné kulovité a oválné vměstky. Nýt je tvořen feritickou ocelí s perlitem vyloučeným po hranicích zrn. Zrna jsou deformována ve směru tváření materiálu nýtu. Tvrdost: lamela $-180 \mathrm{HV}_{0,3}$, nýt $-282 \mathrm{HV}_{0,3}$.
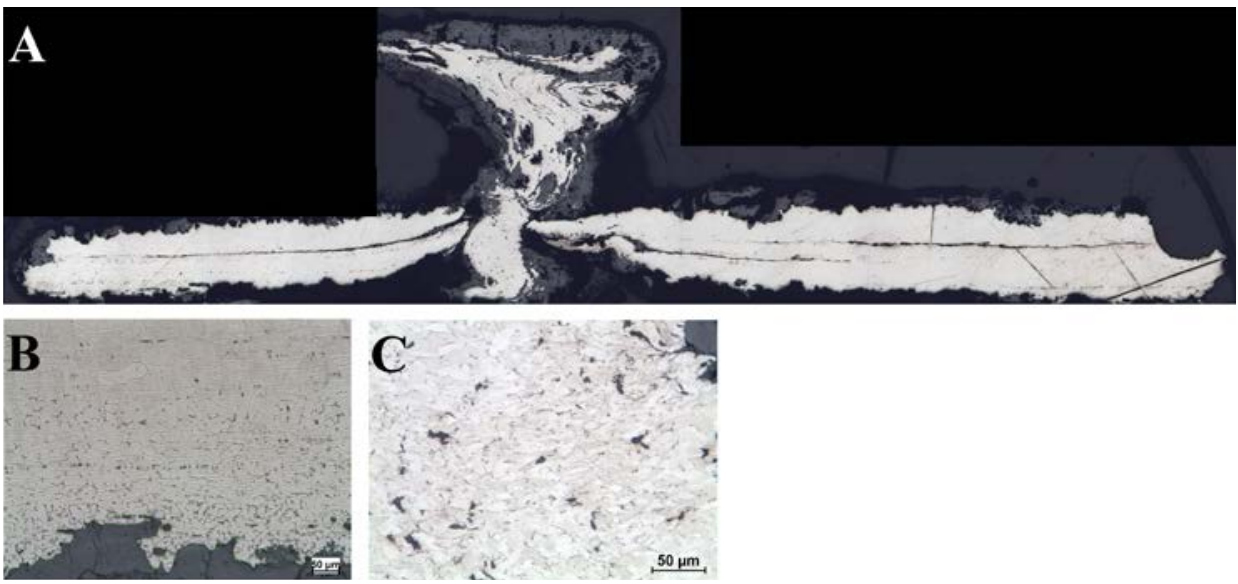

Obr. 9. Lamela 9. A - přehledový snímek přičného řezu lamelou, metalografický výbrus, leptáno Nitalem; B - přechod hrubozrnný/jemnozrnný ferit; $\mathrm{C}$ - feritická ocel s perlitem vyloučeným po hranicích zrn. Foto J. Savková.

Abb. 9. Lamelle 9. A - Übersichtsaufnahme des Lamellenquerschnitts, metallographischer Schliff, mit Nital geätzt; B - Übergang grobkörniges/feinkörniges Ferrit; $\mathrm{C}$ - ferritischer Stahl mit an der Korngrenze ausgeschiedenem Perlit. Foto J. Savková.

Lamela č. 10 (tab. 2, obr. 10)

Lokalita/rok: Landštejn 1977

Rozměry a hmotnost: $121 \times 35 \mathrm{~mm}$; tloušt'ka $1,6 \mathrm{~mm}$; prohnutí $6 \mathrm{~mm}$; hmotnost $29 \mathrm{~g}$

Popis: Jednostranně zkosená lamela se zaoblenými rohy a pěti nýty při okrajích. Čtyři nýty s hlavou o průměru 8-11 mm, jedna hlava nýtu odlomena. Při okraji lamely jsou patrné další dva otvory pro nýty.

Metalografický rozbor: Materiál lamely je tvořen jemnozrnnou a hrubozrnnou feriticko-perlitickou ocelí s nitkovými vměstky. V jemnozrnné oblasti je zřetelný perlit vyloučený po hranicích zrn. V hrubozrnné oblasti jsou viditelná velká perlitická zrna. Nýt vykazuje feriticko-perlitickou mikrostrukturu s perlitem vyloučeným po hranici zrn. Nýt je značně napaden korozí. Tvrdost: lamela - $248 \mathrm{HV}_{0,3}$, nýt - $270 \mathrm{HV}_{0,3}$.

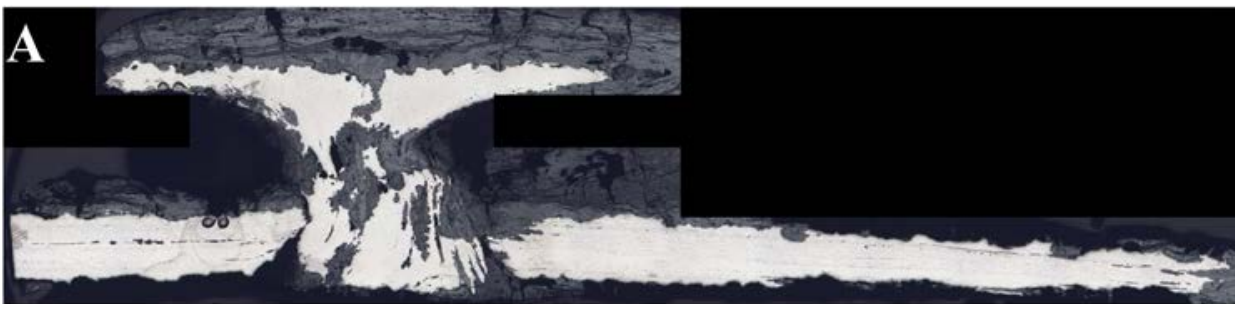



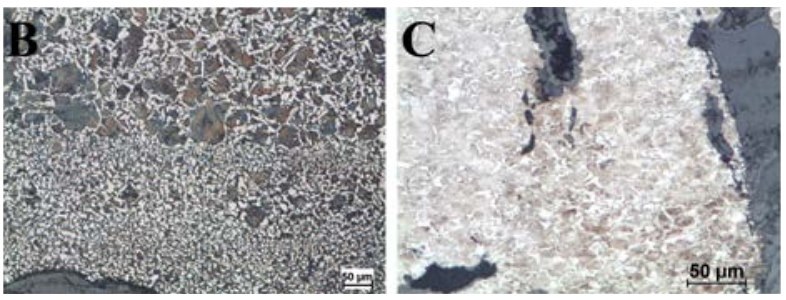

Obr. 10. Lamela 10. A - přehledový snímek př́icného řezu lamelou, metalografický výbrus, leptáno Nitalem; B - feriticko-perlitická struktura (rozhraní mezi jemnozrnnou a hrubozrnnou částí); C-feriticko-perlitická mikrostruktura s feritem vyloučeným po hranici zrn. Foto J. Savková.

Abb. 10. Lamelle 10. A - Übersichtsaufnahme des Lamellenquerschnitts, metallographischer Schliff, mit Nital geätzt; B - ferritisch-perlitische Struktur (Nahtstelle zwischen feinkörnigem und grobkörnigem Teil); C - ferritisch-perlitische Mikrostruktur mit an der Korngrenze ausgeschiedenem Ferrit. Foto J. Savková.

Lamela č. 11 (tab. 2, obr. 11)

Lokalita/rok: Landštejn 1977

Rozměry a hmotnost: $60 \times 42 \mathrm{~mm}$; tloušt'ka $1,1 \mathrm{~mm}$; oboustranné prohnutí $8 \mathrm{~mm}$; hmotnost $12 \mathrm{~g}$ Popis: Obdélná lamela pocházející nejspíš z pasové partie brigantiny, se zaoblenými rohy a dvěma otvory pro nýty.

Metalografický rozbor: Lamela je tvořena hrubozrnným a jemnozrnným feritem s vyloučeným perlitem po hranicích zrn. Jemné nitkovité vměstky byly zaznamenány v obou materiálech. Ve feriticko-perlitické části je jich větší množství. Tvrdost: lamela-180 $\mathrm{HV}_{0,3}$, nýt-224 $\mathrm{HV}_{0,3}$.
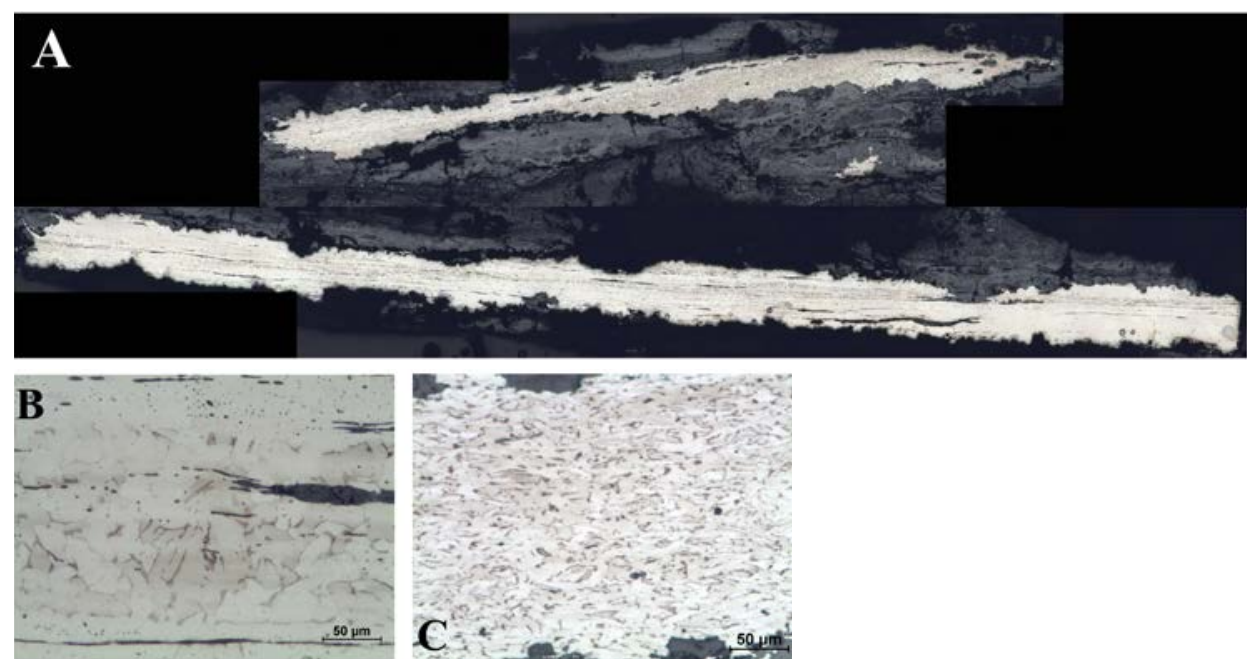

Obr. 11. Lamela 11. A - přehledový snímek příčného řezu lamelou, metalografický výbrus, leptáno Nitalem. B - ferit s perlitem vyloučeným po hranicích zrn (lamela); C - deformovaný jemnozrnný ferit s perlitem vyloučeným po hranicích zrn (nýt). Foto J. Savková.

Abb. 11. Lamelle 11. A - Übersichtsaufnahme des Lamellenquerschnitts, metallographischer Schliff, mit Nital geätzt. B - Ferrit mit an der Korngrenze ausgeschiedenem Perlit (Lamelle); C - verformtes grobkörniges Ferrit mit an der Korngrenze ausgeschiedenem Perlit (Niete). Foto J. Savková.

Lamela č. 12 (tab. 2)

Lokalita/rok: Landštejn 1977

Rozměry a hmotnost: tloušt'ka $1 \mathrm{~mm}$; prohnutí není možné hodnotit kvůli špatnému stavu dochování lamely; hmotnost $8 \mathrm{~g}$

Popis: Fragment lamely neurčitelného tvaru patrně se zaoblenými rohy bez dalších detailů. Metalografický rozbor: Lamela nemá zachované kovové jádro. 
Lamela č. 13 (tab. 2, obr. 12)

Lokalita/rok: Landštejn 1977

Rozměry a hmotnost: $59 \times 60 \times 50 \mathrm{~mm}$; tloušt'ka $1,2 \mathrm{~mm}$; prohnutí $4 \mathrm{~mm}$; hmotnost $10 \mathrm{~g}$

Popis: Trojúhelníková lamela se zaoblenými rohy a dvěma nýty. Jeden nýt se zachovalou hlavou o průměru $10 \mathrm{~mm}$.

Metalografický rozbor: Lamela je tvořena hrubozrnným feritem s perlitem vyloučeným po hranicích zrn. Materiál obsahuje několik hrubších vměstků podélného tvaru. Lamela vykazuje pokročilý stupeň koroze, zachován zůstal velmi malý objem kovu, který neumožňuje relevantní metalografické hodnocení.
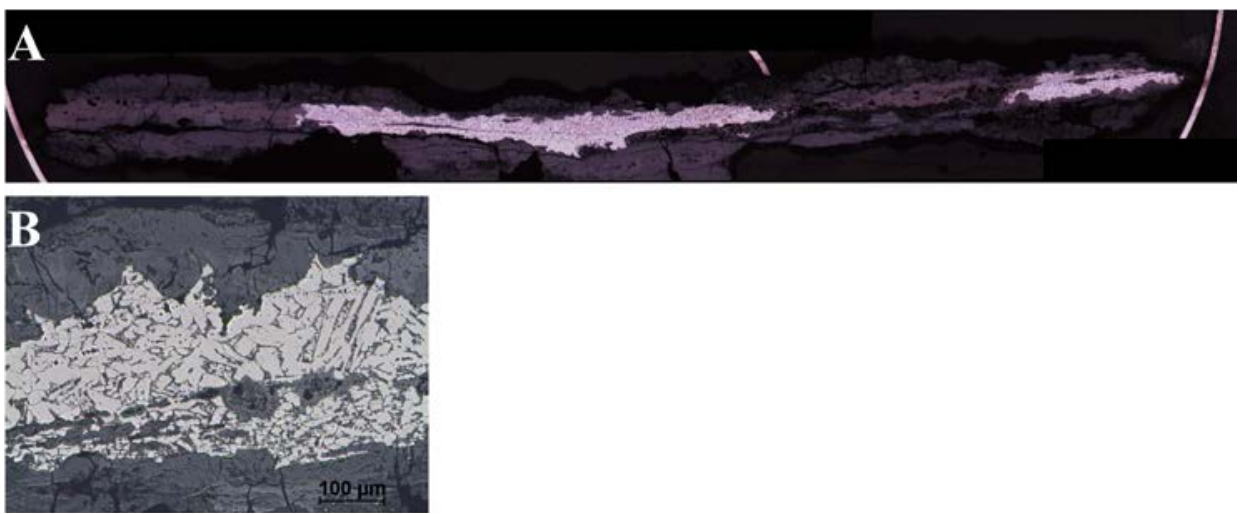

Obr. 12. Lamela 13. A - přehledový snímek př́ičného řezu lamelou, metalografický výbrus, leptáno Nitalem. B - hrubozrnný ferit s perlitem vyloučeným po hranicích zrn. Foto J. Savková.

Abb. 12. Lamelle 13. A - Übersichtsaufnahme des Lamellenquerschnitts, metallographischer Schliff, mit Nital geätzt. B - grobkörniges Ferrit mit an der Korngrenze ausgeschiedenem Perlit. Foto J. Savková.

\section{Lamela č. 14 (tab. 2)}

Lokalita/rok: Nový Herštejn 1977

Rozměry a hmotnost: šířka 38 mm; tloušt'ka 1,8 mm; prohnutí není možné hodnotit kvůli špatnému stavu dochování; hmotnost $12 \mathrm{~g}$

Popis: Neúplná patrně jednostranně zkosená lamela se zaoblenými rohy a dochovaným nýtem s odlomenou hlavou. Nýt odebrán v rámci metalografického vzorku.

Metalografický rozbor: Lamela ani nýt nemají zachované kovové jádro.

Lamela č. 15 (tab. 2)

Lokalita/rok: Nový Herštejn 1977

Rozměry a hmotnost: šířka $35 \mathrm{~mm}$; tloušt'ka 1,6 mm; prohnutí není možné hodnotit kvůli špatnému stavu dochování; hmotnost $8 \mathrm{~g}$

Popis: Fragment nejspíše obdélné, nebo jednostranně zkosené lamely se zaoblenými rohy bez dalších detailů.

Metalografický rozbor: Lamela nemá zachované kovové jádro.

\section{Lamela č. 16 (tab. 2)}

Lokalita/rok: Nový Herštejn 1977

Rozměry a hmotnost: šířka 38 mm; tloušt'ka 1,5 mm; prohnutí není možné hodnotit kvůli špatnému stavu dochování; hmotnost $14 \mathrm{~g}$

Popis: Fragment nejspíše obdélné, nebo jednostranně zkosené lamely se zaoblenými rohy a dvěma nýty s hlavou o průměru 1,1-1,2 $\mathrm{mm}$.

Metalografický rozbor: Kovové jádro lamely i nýtu není dochované v hodnotitelném stavu. 


\section{Lamela č. 17}

Lokalita/rok: Nový Herštejn 1977

Rozměry a hmotnost: rozměry neúplné; tloušt'ka 1,8 mm (silně zkorodovaný povrch); prohnutí není možné hodnotit; hmotnost $8 \mathrm{~g}$

Popis: Neúplná silně zkorodovaná pravděpodobně trojúhelníková lamela se zaoblenými rohy a dvěma nýty bez hlavy.

Metalografický rozbor: Lamela nemá zachované kovové jádro.

\section{Lamela č. 18 (tab. 2)}

\section{Lokalita/rok: Nový Herštejn 1977}

Rozměry a hmotnost: $70 \times 35 \mathrm{~mm}$; tloušt'ka $1,5 \mathrm{~mm}$; prohnutí $4 \mathrm{~mm}$; hmotnost $14 \mathrm{~g}$

Popis: Neúplná patrně jednostranně zkosená lamela se zaoblenými rohy bez dalších detailů. $\mathrm{V}$ př́ípadě tří otvorů není možné s určitostí rozhodnout, zda jde o korozí poškozené otvory pro nýty, nebo o otvory vzniklé pokročilou hloubkovou korozí.

Metalografický rozbor: Lamela nemá zachované kovové jádro.

\section{Hodnocení formálních znaků lamel}

S výjimkou lamel z hradu Nového Herštejna jde o nestratifikované nálezy, které neumožňují bližší časové zařazení (Durdík 1983, 14). Kolekce lamel pocházející z Nového Herštejna byla získána při archeologickém výzkumu v letech 1973-1976. V rámci dokumentačních prací byl rozšířen starší neodborný výkop provedený kdyňským učitelem (Durdík-Procházka 1978, 2) při vnitřní stěně bašty zajišt’ující východní stranu hradního areálu (Durdík-Procházka 1978; Procházka 1998, 220). V rámci sondy došlo také k částečnému odkryvu severní zdi mladší budovy přiložené k obvodové hradbě zajištěné na vnější straně polookrouhlou věžicí, zvané Panenská bašta, zajišt'ující první bránu a přístupovou komunikaci mezi první a druhou bránou (Procházka 1998, 222). V komunikačně méně vytíženém koutu tvořeném nádvorní zdí bašty se zazděným vstupem a severní zdí mladší budovy (obr. 14) došlo v průběhu první poloviny 15. století ke kumulaci vrstev tvořených životními nečistotami a dochovala se část destrukce roubené nástavby mladší stavby. Tato situace byla překryta zánikovým horizontem hradu z doby po roce 1475 . V souvrství tvořeném vrstvami II, III a IV (Durdík-Procházka 1978, 47-49; Procházka 1998, 217, obr. 20) byla nalezena kolekce čítající 56 kusů železných lamel zbroje různé velikosti, která představovala první stratifikovaný soubor fragmentů lamelové zbroje v Čechách (Durdík-Procházka 1978, 42). ${ }^{3}$ Soubor sestával ze čtyř kusů o rozměrech $1,3 \times 2 \mathrm{~cm}$, čtyř kusů o rozměrech $4 \times 2,5 \mathrm{~cm}$, dvou kusů o rozměrech $4,5 \times 25 \mathrm{~cm}^{4}$, jednoho kusu o rozměrech $4 \times 4,5 \mathrm{~cm}$, dvaceti kusů o rozměrech $7 \times 4,5 \mathrm{~cm}$ a dalších, převážně neúplných lamel v pokročilém stadiu koroze (Durdík-Procházka 1978, 23, 39 a 43; Procházka 1998, 222). S ohledem na koncentraci lamel na velmi omezeném prostoru by bylo možné s velkou opatrností spíše spekulovat o možnosti, že by nalezený soubor lamel mohl představovat torzo jediné zbroje. V pozůstalosti T. Durdíka se však z této kolekce nachází pouze malý zlomek. Tato spekulace tedy nejspíše zůstane nepotvrzená. Ostatní lamely jsou nezvěstné. Nelze ovšem vyloučit, že k jejich ztrátě mohlo dojít při povodních v roce 2002, kdy byla značně poničena pracovna T. Durdíka situovaná v přízemí Archeologického ústavu. Při povodních došlo k nemalým ztrátám nejen na dokumentaci pořízené T. Durdíkem, ale také na zde uložených artefaktech. Dochované lamely se pak staly součástí této práce.

Ze souboru hodnocených lamel nepochybně pocházejících z několika zbrojí ze tří hradních lokalit umožňují bližší dataci pouze lamely z hradu Nového Herštejna. Čtyři exempláře představují jednostranně zkosené lamely (č. 1 z Přimdy, 3, 4 a 10 z Landštejna). Čtyři exempláře z hradu

\footnotetext{
3 Vyobrazení na s. 42 však postihuje pouze část nalezené kolekce lamel.

4 U těchto lamel nelze s jistotou říci, zda je údaj správný, nebo zda došlo k chybě, resp. opomenutí desetinné čárky. Rozměr lamel mohl být

$4,5 \times 2,5 \mathrm{~cm}$. V př́padě správného údaje by mohlo jít o pásovou lamelu, která může krýt oblast hrudi. Tento typ lamel se však hojně uplatňuje také

v konstrukci šorců (srov. např. Knápek 2011, 61-64; Schmitt 2008, 164; Marek 2008, 92 obr. 6, 100 obr. 15; Žákovský 2009, 417 s přehledem další lit.).

5 Za konzultaci děkuji Mgr. Krzysztofovi Cackowskému z Univerzity Mikuláše Koperníka v Toruni.
} 
Landštejna představují lamely obdélné (č. 5, 6, 7 a 11), dva exempláře z téže lokality přináleží k lamelám lichoběžníkovým (č. 8 a 9). Tyto lamely se řadí k obecně nejběžnějším a vyskytují se v širším evropském kontextu v různém prostředí (namátkou Krajíc 2003, 130; Scalini 2003, 388, obr. 11a, b; Marek 2008, 98 obr. 12 a 13, 99 obr. 14). Všechny lamely měly zaoblené rohy a rovněž všechny lamely nesou celé nýty nebo jejich pozůstatky (viz tab. 1 a 2). Sedm exemplářu z hradu Landštejna a Nového Herštejna nebylo možné kvůli jejich špatnému stavu dochování blíže určit, nebo bylo možné pouze určení založené na jisté míře pravděpodobnosti, a to spíše jako lamely obdélné, lichoběžníkovité nebo jednostranně zkosené (č. 2, 12, 14, 15, 16, 17, a 18). Tyto lamely se mohly obecně uplatnit nejen v konstrukci brigantin při ochraně trupu (Scalini 2003, 391), ale také v konstrukci sukničky a kombinovaných zbrojí (Scalini 2003, 386 obr. 7; Spindler 2004, 16-17; Žákovský 2009, 416). Jeden exempláŕ z Nového Herštejna pak představuje lamelu trojúhelníkovitou (č. 13). I přesto, že se použití lamelové a rozvoj kombinované zbroje časově překrývají (např. Gamber 1953; Žákovský 2009, 413-418), přikláníme se v př́ípadě hodnoceného souboru (srov. též Durdík-Procházka 1978, 42) se značnou opatrností k souvislosti nalezených lamel se segmentovou lamelovou zbrojí, která v zásadě směřovala v průběhu 16. století ke vzniku severoitalských corazzin (např. Scallini 2003, 388 obr. 11b, 395 obr. 24 a, b).

$\mathrm{S}$ ohledem na charakter kolekce a s přihlédnutím k počtu lokalit, z nichž pochází, není možná rekonstrukce počtu zbrojí, ke kterým lamely původně přináležely. Nicméně v případě dvou lamel z hradu Landštejna (č. 4 a 6 ) s nýty pokrytými mosazí by bylo možné uvažovat o jejich vzájemné souvislosti a snad mohly tvořit součásti jedné zbroje.

Celkem 18 lamel bylo vyrobeno ze železa různé kvality nebo nízkouhlíkové oceli různé tvrdosti a houževnatosti. Všechny hodnocené lamely se řadí k obecně menším exemplářům. Bez zajímavosti není ani snaha o finální úpravu nýtů. Ve dvou př́ípadech došlo k úpravě hlavy nýtu (č. 4 a 6) vrstvou mosazi. Nejspíše v jednom př́padě (č. 1) z hradu Přimdy mohl být povrch hlavy nýtu pokryt cínem. V př́ípadě povrchové úpravy nýtů u lamel č. 4 a 6 z Landštejna byly hlavy nýtů nejprve pokryty vrstvou bronzu a ta následně překryta vrstvou mosazi.

\section{Grafické záznamy série}

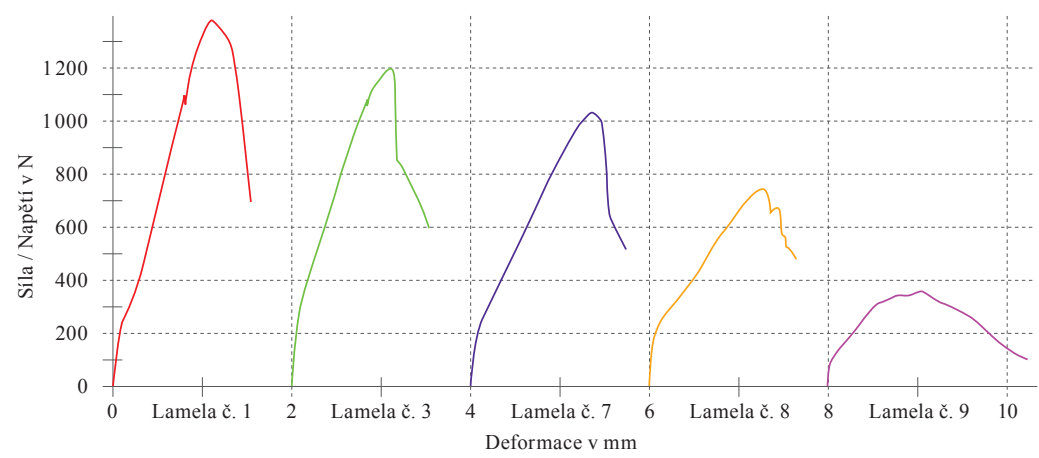

\section{Výsledky zkoušek}

\begin{tabular}{|c|c|c|c|c|}
\hline $\mathrm{Nr}$ & Lamela č. & $\begin{array}{c}\mathrm{F}_{\max } \\
\mathrm{N}\end{array}$ & $\begin{array}{c}\mathrm{dL} \text { př } \mathrm{F}_{\max } \\
\mathrm{mm}\end{array}$ & $\begin{array}{c}\mathrm{h}_{0} \\
\mathrm{~mm}\end{array}$ \\
\hline 1 & 1 & 1380 & 1,1 & 0,499 \\
\hline 2 & 3 & 1200 & 1,1 & 0,499 \\
\hline 3 & 7 & 1030 & 1,4 & 0,445 \\
\hline 4 & 8 & 742 & 1,3 & 0,496 \\
\hline 5 & 9 & 359 & 1,0 & 0,495 \\
\hline
\end{tabular}

\section{Statistika}

\begin{tabular}{|c|c|c|c|c|c|c|c|}
\hline $\begin{array}{c}\text { Série } \\
\mathrm{n}=5\end{array}$ & Zk. è. & $\begin{array}{c}\mathrm{F}_{\max } \\
\mathrm{N}\end{array}$ & $\begin{array}{c}\mathrm{dL} \mathrm{při} \mathrm{F}_{\max } \\
\mathrm{mm}\end{array}$ & $\begin{array}{c}\mathrm{F}_{\text {lom }} \\
\mathrm{N}\end{array}$ & $\begin{array}{c}\mathrm{dL} \mathrm{lom.} \\
\mathrm{mm}\end{array}$ & $\begin{array}{c}\mathrm{d}_{0} \\
\mathrm{~mm}\end{array}$ & $\begin{array}{c}\mathrm{S}_{0} \\
\mathrm{~mm}^{2}\end{array}$ \\
\hline$\overline{\mathrm{x}}$ & 3 & 943 & 1,2 & 477 & 1,7 & 8 & 50,27 \\
\hline $\mathrm{s}$ & 2 & 402 & 0,1 & 226 & 0,3 & 0,000 & 0,00 \\
\hline $\mathrm{U}$ & 52,70 & 42,67 & 11,26 & 47,34 & 16,22 & 0,00 & 0,00 \\
\hline
\end{tabular}

Obr. 13. Vyhodnocení Small Punch Testu hodnocených lamel. Úprava J. Volák.

Abb. 13. Auswertung des Small Punch Testes der untersuchten Lamellen. Erstellt von J. Volák. 


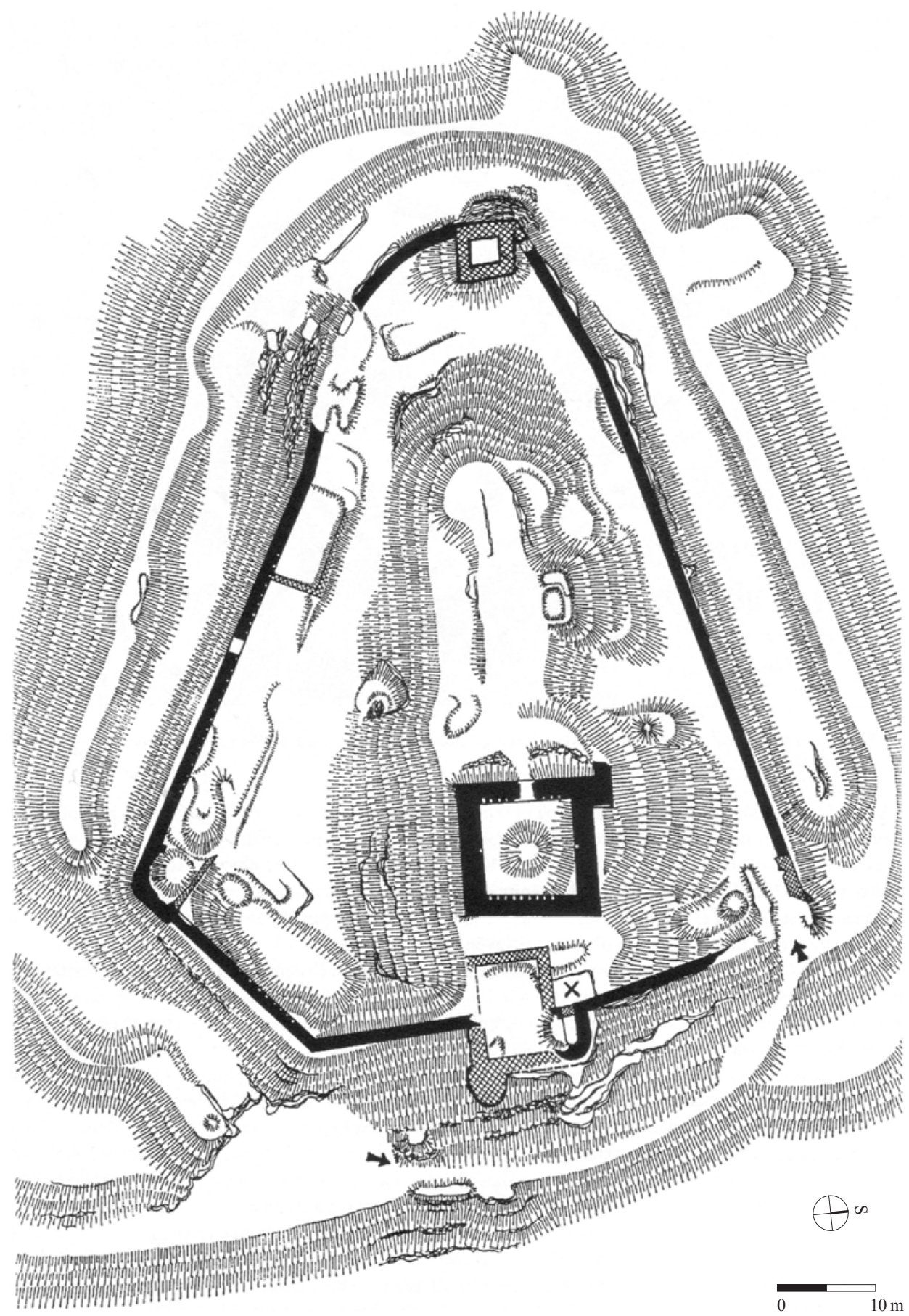

Obr. 14. Nový Herštejn. Zaměření hradního areálu z roku 1998. Černě zdivo z doby před polovinou 14. století, křižzovaně zdivo patrně z 15. století. Kř́ǐ̌kem označeno místo nálezu koncentrace lamel segmentové zbroje. Podle Procházka 1998, 208. Abb. 14. Nový Herštejn. Vermessung des Burgareals aus dem Jahr 1998. Schwarz: Mauerwerk aus der Zeit vor Mitte 14. Jhdt., Kreuzschraffur: offenbar aus dem 15. Jhdt. stammendes Mauerwerk Mit Kreuz gekennzeichnet: Fundort einer Lamellenkonzentration von Segmentrüstungen. Nach Procházka 1998, 208. 


\section{Závěr a diskuse}

Soubor železných lamel byl podroben základní metalografické analýze s cílem vytvoření přehledu použitého základního materiálu sloužícího $\mathrm{k}$ jejich výrobě a materiálových vlastností ovlivňujících kvalitu a funkční vlastnosti zbroje. Při hodnocení jednotlivých lamel byl přednostně odebírán materiál z jejich okraje tak, aby byla možná zpětná rekonstrukce jednotlivých exemplářu (viz tab. 1 a 2). Předmětem zájmu pak byla také místa spojení jednotlivých lamel pomocí nýtů vykazujících různé povrchové úpravy, které mají vliv zejména na estetické kvality zbroje (např. Durdík 1983, 14). Nelze však vyloučit ani jisté osobní preference výrobce zbroje nebo jejího nositele. Při povrchové úpravě nýtů se uplatnila především slitina mědi, resp. mosaz (lamely č. 4 a 6), ale také bronz a cín (patrně lamela č. 1). Nejen překrytí hlav nýtů mosazí, ale už samo pokrytí cínem nebo bronzem dodalo vystupujícím nýtům zajímavý kovový lesk. Doklady takto zdobených brigantin máme z našeho i zahraničního prostředí také např. z hradů Leuchtenštejnu (Kouřil-Prix-Wihoda 2000, 60), Dolní Štěpanice (Hošek 2003, 85), Rychleby (Goš 1976, 296), Šostýn (Tichánek 2008, 122), Szerba (Williams 2009, 213) či Sachsendorf (Starley 2005, 36). Některé nýty mohly být opatřeny také drobnými rozetami (nap̌r. Peine 2004, 54) či doplněny o další aplikace (Thordeman 1940a, obr. 32).

U lamel s dochovaným kovovým jádrem bylo možné pozorovat značný rozptyl mikrostruktury, a tedy i vstupního výrobního materiálu, který ovlivnil nejen vlastnosti jednotlivých lamel, ale rovněž se odrazil na stavu jejich dochování. Ve třech př́ípadech byla mikrostruktura tvořena výhradně hrubozrnným feritem (lamely č. 2, 5 a 8). Běžněji se vyskytovala směs jemně zrnitého a hrubozrnného feritu v podobě vrstev korespondujících $\mathrm{s}$ technologickým postupem výroby zdrojového materiálu, jakož i samých lamel (pro srovnání např. Williams 2009, 213). Tento jev vzniká při skovávání více rozdílných materiálových zdrojů použitých při výrobě lamely a vícenásobném překládání zdrojového materiálu lamely. Zjemnění mikrostruktury nastává také v některých př́padech v okolí vměstků, kde dochází k nalegování materiálu žádoucími prvky, např. Si (lamely č. 3, 9, 10, 11 a 13 z hradu Landštejna). Ve třech případech byla zjištěna feriticko-perlitická mikrostruktura tvořící 90 \% objemu hmoty železného jádra lamely (č. 3, 7 a 10 z Landštejna). Naopak lamela č. 1 z Přimdy je jednoznačně složena ze dvou výrazně odlišných materiálů. Mikrostruktura jedné poloviny je tvořena martenzitem a druhé hrubozrnným feritem. Obdobná struktura materiálu byla zaznamenána u lamely č. 6 , u níž bylo možné pozorovat v okrajové části lamely martenzitickou strukturu. Ze srovnání s hodnocenými soubory z jiných lokalit (Williams 2009, 213) lze usoudit, že v př́padě této lamely byl zpracován zlomkový materiál vyšší kvality. U všech hodnocených lamel i nýtů byl zachycen značný rozptyl ve velikosti, tvaru i množství vměstků. Obdobné materiálové spektrum bylo zaznamenáno při metalografickém hodnocení železných lamel pocházejících z hradu Lopaty (Williams 1999, 27-28). Tvrdost jednotlivých lamel se lišila v závislosti na jejich mikrostruktuře a technologickém postupu výroby. Tvrdost feritického materiálu použitého k výrobě lamel se pohybovala $\mathrm{v}$ rozmezí $160-176 \mathrm{HV}_{0,3}$. Feritická ocel použitá na nýtech však v řadě případů vykazovala vyšší tvrdost. $V$ př́ípadě výskytu feriticko-perlitických struktur vykazovaly lamely vyšší tvrdost pohybující se v rozmezí $214-240 \mathrm{HV}_{0,3}$. V př́ípadě martenzitu dosahovala tvrdost hodnoty $280 \mathrm{HV}_{0,3}$. Pro srovnání je možné uvést tvrdost hodnocených augšpurských plátových zbrojí, u kterých byla naměřena tvrdost v rozmezí 305-379 $\mathrm{HV}_{0,3}$, a italské plátové zbroje 15 . století dosahují tvrdosti kolem 210-279 $\mathrm{HV}_{0,3}$ (Williams 2003, 78, 118, 120, 362). Kvalitu zbroje by samozřejmě bylo možné posuzovat i podle místa jejího původu. Přesné určení však umožňují pouze platnéřské značky, jejichž výskyt v kolekci nebyl zaznamenán (srov. např. Schmitt 2008, 165).

Mechanické vlastnosti (síla vs. deformace) byly stanoveny prostřednictvím Small Punch Testu. Šlo o lamely č. 1 z Přimdy, 3, 7, 8 a 9 z Landštejna (obr. 14). Cílem testu bylo určení síly vedoucí ke kolapsu, resp. protržení materiálu. Dle našeho předpokladu vykazovala nejvyšší odolnost lamela č. 1 (tab. 1, obr. 1) tvořená dvěma materiály o přibližně stejném podílu. Materiál v horní části je tvořen martenzitickými jehlicemi s relativně nízkou vměstkovitostí a hrubozrnným feritem s malým podílem vměstků. Tato lamela odolávala až do působení síly o hodnotě 1380 N. Tvrdost martenzitické části lamely dosahovala hodnoty $440 \mathrm{HV}_{0,3}$, feritická část pak 
hodnoty $185 \mathrm{HV}_{0,3}$. Druhou nejvyšší odolnost proti protržení vykazuje dle grafického vyjádření (obr. 14) lamela č. 3 z Landštejna (tab. 1, obr. 3) s mikrostrukturou tvořenou středovým pásem s feriticko-perlitickou strukturou a okraji z hrubozrnného feritu s obecně vyšší vměstkovitostí. Tato lamela odolávala až do působení síly $1200 \mathrm{~N}$. Tvrdost lamely kolísala v různých částech svého jádra v rozmezí 214-240 $\mathrm{HV}_{0,3}$. Lamela č. 7 z téže lokality (tab. 1, obr. 7) je tvořena feriticko-perlitickou ocelí s feritem vyloučeným po kraji perlitu. Lamela v místě metalografického výbrusu obsahovala několik hrubších podélných vměstků. Hodnocený vzorek odolával až do působení síly $1030 \mathrm{~N}$. Naměřená tvrdost použitého materiálu dosahovala hodnoty $282 \mathrm{HV}_{0,3}$. V této souvislosti je však nutné upozornit na skutečnost, že vzorek č. 3 měl ve srovnání se vzorky z lamel č. 1 a 3 o 0,054 mm menší tloušt'ku. Tato skutečnost byla způsobena horší mírou dochování kovového jádra lamely. V př́ípadě možnosti dosažení stejné tloušt'ky vzorku (viz obr. 14) by se odolnost této lamely více blížila odolnosti lamely č. 3. Vzorek odebraný z lamely č. 8, pocházející rovněž z Landštejna (tab. 1, obr. 8), vyrobené z hrubozrnného feritu s velkými vměstky odolával až do působení síly o hodnotě $742 \mathrm{~N}$. Naměřená tvrdost použitého materiálu dosahovala $176 \mathrm{HV}_{0,3}$. Nejmenší odolnost proti protlačení vykazoval vzorek z lamely č. 9 (tab. 2, obr. 9) vyrobené z jemnozrnného a hrubozrnného feritu, nalezené na Landštejně. Oba materiály odděloval kovářský svar procházející středem lamely. K destrukci použitého materiálu došlo při působení síly $359 \mathrm{~N}$. Naměřená tvrdost lamely dosahovala hodnoty $180 \mathrm{HV}_{0,3}$. Nejvyšší míra deformace materiálu použitého k výrobě hodnocených lamel byla zaznamenána u vzorku odebraného z lamely č. 7 (tab. 1, obr. 7) vyrobené z feriticko-perlitické oceli o tvrdosti $282 \mathrm{HV}_{0,3}$.

Provedené materiálové analýzy přinesly nejen nové informace týkající se variability materiálu použitého k výrobě hodnocených lamel, ale také nové poznatky z oblasti kvalitativního spektra lamel použitých v konstrukci zbroje. Z hlediska kvality, vyjádřené tvrdostí a houževnatostí hodnocených lamel, je možné považovat za nejkvalitnější exempláře z Přimdy (č. 1) a Landštejna (č. 3 a 7). Z hlediska kvality použitých lamel je pak zajímavá, byt’ nikterak překvapující skutečnost, že z jedné lokality, $\mathrm{v}$ tomto př́ípadě z hradu Landštejna, pochází lamely výrazně odlišné kvalitativní úrovně, vyjádřené nejen tvrdostí a odolností lamel proti protlačení, ale také estetickými kvalitami. Za současného stavu poznání kolekce lamel z hradu Landštejna se přikláníme k předpokladu, že lamely by mohly pocházet spíše z několika odlišných zbrojí. Nicméně není možné vyloučit ani rovněž značně pravděpodobnou možnost, že jedna zbroj mohla být sestavena z lamel vykazujících jisté kvalitativní rozdíly co se týče materiálových vlastností. I přestože získané informace vnáší nové světlo do problematiky kvality použitých lamel, vypovídají o celkové odolnosti a dalších vlastnostech zbroje jen částečně. Při komplexním hodnocení kvality jednotlivých zbrojí by bylo nutné zohlednit nejen vlastnosti dalších materiálů použitých při její výrobě, ale také vlastnosti použitých nýtů, které měly nepochybně vliv na celkovou soudržnost zbroje při extrémním namáhání. Zvolená forma testování houževnatosti zbroje (Small Punch Test) umožnila hodnocení její odolnosti při působení stoupající síly. Domníváme se však, že v případě působení dynamického zatížení, které by lépe odráželo namáhání zbroje např. př́i nárazu čepele, hrotu střely nebo projektilu z palné zbraně, by bylo hodnocení houževnatosti zkoumaných lamel velmi podobné. Relevantní simulace takovéhoto zatížení však není, s ohledem na předem stanovený požadavek minimálního zásahu do lamel, a tedy minimálního množství odebraného materiálu, prozatím reálná. Z hlediska volby použitého materiálu je u celé kolekce hodnocených lamel patrná snaha směřující k ideálnímu kompromisu mezi tvrdostí a odolností proti protlačení, resp. průrazu. V př́ípadě lamel vykazujících nižší míru tvrdosti a odolnosti proti protlačení, vyrobených zejména $\mathrm{z}$ feritu, se přikláníme spíše k využití méně kvalitního, ale obecně dobře dostupného materiálu. Přestože provedené materiálové hodnocení přineslo nové informace o kvalitativním spektru lamel z brigantin nalezených na několika hradních lokalitách v Čechách, nelze prozatím formulované závěry - s ohledem na počet hodnocených vzorků - zcela zobecnit. Výsledky materiálových analýz však přinesly podstatné informace o materiálových vlastnostech lamel použitých při výrobě tohoto typu zbroje a také o velmi vysoké míře odolnosti některých lamel (především lamela č. 1), která dosahuje přibližně 60 \% míry odolnosti moderních ocelí. Další možnosti interpretace výsledků hodnocení použitého materiálu by přineslo určení provenience nalezených 
součástí zbrojí - to ovšem vzhledem ke špatnému stavu dochování lamel a absenci kovářských značek na nich, není reálné.

Studie byla vyhotovena za podpory projektu SGS-2015-059 financovaného Interní grantovou agenturou ZČU v Plzni.

\section{Literatura}

BAIERL, P., 2010: Nebezpečí detektorů, Hláska XXI, 12-13.

BELCREDI, L., 1989: Terminologie, třídění a kód středověkých kovových předmětů - Terminologie, Klassifizierung und Kode mittelalterlicher metallischer Gegenstände, AH 14, 437-472.

BENEŠ, C., 1991: Vývoj ochranné zbroje II-V. Muzejní a vlastivědná práce 29, ČSPS 99, 13-24, 74-93, 139-150, 196-217.

- 1992: Zbroj. Stráňavy.

BLACKMORE, H. L., 1965: Arms and armour. London.

BLAIR, C., 1979: European Armour circa 1066 to circa 1700. London.

ČIŽMÁ̌̌, M., 2006: Detektor ano, nebo ne? Archeologie a detektory kovů - The metal detector: yes or no? Archaeology and metal detectors, AR LVIII, 284-289.

DURDÍK, T., 1983: Středověké zbraně. Sbírky okresního muzea v Chrudimi. Chrudim.

- 1988: Výzkum manského domu na Křivoklátě (Předběžné sdělení) - Erforschung des Lehensmannshauses in Křivoklát (Vorbericht), AH 13, 285-298.

- 1995: Manský dům na Křivoklátě - „malé české Pompeje“, Starožitnosti a užité umění, č. 4, 8-9.

- 2006: Přimda - die älteste Steinburg in Böhmen, Forschungen zu Burgen und Schlösser 9, 95-103.

- 2007: Hrad Přimda - Die Burg Přimda. Vlastivědná knihovnička poučnosti přátel starožitností sv. 14. Praha.

DURDÍK, T.-HAVLOVÁ, M., 1990: Hrad Landštejn. České Budějovice.

DURDÍK, T.-PROCHÁZKA, Z., 1978: Nový Herštejn. Nálezová zpráva č. j. 800/78 ulož. v Archivu nálezových zpráv Archeologického ústavu AV ČR, Praha, v. v. i.

- 2002: Zjiššovací výzkum hradu Nového Herštejna v roce 2001. ZČAS Supplément 49, 27, obr. 11.

FROLÍK, J.-MUSIL, J., 2015: Katalog archeologických nálezů z hradu Košumberka. 1. díl: kovové předměty. Chrudim.

GAMBER, O., 1953: Harnischstudien V. Stilgeschichte des Plattenharnisches von den Anfängen bis um 1440, Jahrbuch der Kunsthistorischen Sammlungen in Wien 50, 53-92.

GOŠ, V., 1976: Vzácná zbroj z hradu Rychleby, Severní Morava 31, 51-53.

HLOŽEK, J.-SAVKOVÁ, J.-VAŘEKA, P., v př́ipravě: Metalografické vlastnosti součástí středověkého pluhu. HOŠEK, J., 2003: Metalografie ve službách archeologie. Praha.

JÁNSKÝ, J., 2004: Kronika česko-bavorské hranice. Díl IV. (1458-1478) doba krále Jiřího a první období jagellonské vlády - boje s křižáky a odboje Zelenohorské jednoty a bocklerů. Domažlice.

KELSO, W. M.-LUCCKETTI, N. M.-STRAUBE, B. A., 1998: Jamestown Rediscovery IV. Richmond.

KLUČINA, P.-ROMAŇÁK, A., 1983: Člověk, zbraň a zbroj v obraze doby I. (5.-17. století). Praha.

KNÁPEK, A., 2011: Plátový kabátec ze Starého Jičína, Vlastivědný sborník Novojičínska 61, 61-64.

KOUŘIL, P., 2009: Hrad Javorník: březen 1428 - záríi 1434. Př́íspěvek k poznání hmotné kultury doby husitské ve Slezsku, ČSM B 58, 1-15.

KOUŘIL, P.-PRIX, D.-WIHODA, M., 2000: Hrady českého Slezska. Brno - Opava.

KRAJÍC, R., 2003: Sezimovo Ústí. Archeologie středověkého poddanského města 3. Kovárna ze Sezimova Ústí a analýza výrobků ze železa. Praha - Sezimovo Ústí - Tábor.

KUNA, M., 2006: Detektory kovu v archeologii, AR LVIII, 323-328.

MAREK, L., 2008: Medieval Armour from Szczerba Castle, Acta Militaria Medievalia IV, 87-124.

MĚCHUROVÁ, Z., 1997: Konůvky - zaniklá středověká ves ve Ždánickém lese. Studie archeologického ústavu Akademie věd ČR v Brně XVII/1. Brno.

MÜLLER, H., 1957: Historische Waffen. Kurze Entwicklungsgeschichte der Waffen vom Frühfeudalismus bis zum 17. Jahrhundert. Berlin.

NEKUDA, V., 1985: Mstěnice. Zaniklá středověká ves u Hrotovic. Hrádek - tvrz - dvůr - předsunuté opevnění. Brno.

NEUSTUPNÝ, E., 1986: Nástin archeologické metody - An outline of the archaeological method, AR XXXVIII, 525-549.

- 2007: Metoda archeologie. Plzeň. 
PEINE, H.-W., 2004: Ein Blick in die Waffenkammer des Hauses Herbede an der Ruhr. In: Das Brigantinen-Symposium auf Schloss Tirol (Rachewiltz, S.-Spindler, K.-Stadler, H., edd.), 40-77.

PROCHÁZKA, Z., 1998: Nové poznatky z výzkumu hradu Nového Herštejna, CB 6, 205-228.

SCALINI, M., 2003: Corazzine e bacinetti dalla Rocca di Campiglia. In: Campiglia. Un castello e il suo territorio II. Indagine archeologica (Bianchi, G., ed.), 382-396. Firenze.

SCHMITT, A., 2008: Burg Tannenberg bei Seeheim-Jugenheim. Eine spätmittelalterliche Ganerburg im Licht der archäologischen Funde. Darmstadt.

SPINDLER, K., 2004: Die Brigantine von Schloss Tirol in ihrem archäologischen und historischen Umfeld. In: Das Brigantinen-Symposium auf Schloss Tirol (Rachewiltz, S.-Spindler, K.-Stadler, H., edd.), 7-19. SMRŽ, Z., 2006: Archeologové, mrcasníci a detektoráři, AR LVIII, 321-323.

STARLEY, D., 2005: Brigandines and Jackplates. Datasheet 36. The Finds Research Group AD700-1700. TICHÁNEK, J., 2008: Hrad a panství Šostýn. Opava.

THORDEMAN, B., 1940: Armour from the battle of Wisby 1361. Vol. 1. Text. Stockholm.

- 1940a: Armour from the battle of Wisby 1361. Vol. 2. Plates. Stockholm.

- 2001: Armour from the battle of Wisby 1361. New York.

WAGNER, E.-DURDÍK, J.-DROBNÁ, Z., 1956: Kroje, zbroj a zbraně doby předhusitské a husitské. Praha. WILLIAMS, A., 1999: The metallurgy of some armour from Bohemia. In: Archaeometallurgy in the Central Europe. Východoslovenský Pravek Special Issue (Mihok, L.-Miroššayová, E., edd.), 27-40. Nitra.

- 2003: The Knight and the Blast Furnace: A History of the Metallurgy of Armour in the Middle Ages and the Early Modern Period. Leiden - Boston - Köln.

-2009: The metallurgy of brigandines from Szczerba and Kempten, Acta Militaria Mediaevalia V, $213-219$.

ZITOVÁ, L., 201: Archeologické doklady brigantin ze 14.-15. století ve středoevropském prostoru. Plzeň. Katedra archeologie, Fakulta filozofická, Západočeská univerzita v Plzni, nepublikovaná bakalářská práce.

ŽÁKOVSKÝ, P., 2009: Hromadný nález nejstarších platnéřských prací z území Moravy (?). Př́íspěvek k poznání tzv. kombinovaných zbrojí - Ein Sammelfund der ältesten Plattnerarbeiten auf mährischem Gebiet (?). Ein Beitrag zum Verständnis sogenannter kombinierter Rüstungen, AH 34, 409-444.

\section{Zusammenfassung}

\section{Einige Anmerkungen zur Materialstruktur und zu den mechanischen Eigenschaften der Segmente von Lamellenpanzern}

Obwohl Lamellenpanzer, sog. Brigantinen, zu den fortschrittlichen Typen mittelalterlicher Rüstungen bestehen, vermissen wir bei den meisten erhalten gebliebenen Exemplaren, Torsi oder Einzelfunden von Lamellen Informationen über ihre Materialeigenschaften, über Art und Weise ihrer Verarbeitung und über ihre Qualität. Die Ergebnisse jüngst durchgeführter metallographischer Analysen von bislang nicht veröffentlichten, von den Burgarealen Přimda, Landštejn und Nový Herštejn stammenden Eisenlamellen werfen mehr Licht auf die Problematik, wie dieser Rüstungstyp konstruiert war und besonders dann auch darauf, welches Materialspektrum bei seiner Herstellung verwendet wurde. Die ausgewertete Sammlung besteht aus 18 Exemplaren verschieden geformter Eisenlamellen mit unterschiedlicher Anzahl erhaltener Nieten. Auch trotz der stabilen und festen Oberfläche der untersuchten Lamellen war ihr Metallkern nicht in allen Fällen erhalten geblieben oder hat wegen ihres schlechten Erhaltungszustandes keine metallographische Auswertung erlaubt. Mit Ausnahme der Lamellen von der Burg Nový Herštejn handelt es sich um nicht stratifizierte Funde, die keine nähere zeitliche Zuordnung erlauben. Die Lamellenkollektion von Nový Herštejn wurde anhand von archäologischem Material in die erste Hälfte des 14. Jahrhunderts datiert. Die gesamte Situation war vom Wüstungshorizont der Burg aus der Zeit nach 1475 überdeckt.

Die untersuchten Lamellen stammen zweifellos von mehreren Rüstungen und von drei Burg-Fundstellen, von denen lediglich die Lamellen von Burg Herštejn eine nähere Datierung erlauben. Vier Exemplare stellen einseitig abgeschrägte Lamellen dar (Nr. 1 von Burg Přimda, 3, 4 und 10 von Burg Landštejn). Vier Exemplare von der Burg Landštejn sind längliche Lamellen (Nr. 5, 6, 7 und 11), zwei Exemplare von derselben Fundstelle zählten zu den trapezförmigen 
Lamellen (Nr. 8 und 9). Sieben Exemplare von Burg Landštejn und Burg Nový Herštejn konnten wegen ihres schlechten Erhaltungszustands nicht näher bestimmt werden, oder ihre Bestimmung war nur bis zu einem gewissen Wahrscheinlichkeitsgrad möglich, und zwar eher als längliche, trapezförmige oder einseitig abgeschrägte Lamellen (Nr. 2, 12, 14, 15, 16, 17 und 18). Ein Exemplar von Burg Nový Herštejn stellt dann eine dreieckige Lamelle dar (Nr. 13). Im Hinblick auf den Charakter der Kollektion und unter Berücksichtigung der Anzahl der Fundstellen, von denen sie stammen, kann die Anzahl der Rüstungen, zu denen die Lamellen ursprünglich gehörten, nicht rekonstruiert werden. Nichtsdestotrotz könnte man bei zwei mit Nieten bedeckten Lamellen von Burg Landštejn (Nr. 4 und 6) dahingehend einen gemeinsamen Zusammenhang in Betracht ziehen, dass sie Bestandteil von ein und derselben Rüstung gewesen sein könnten. Nicht uninteressant ist auch die Bemühung um die Endbearbeitung der Nieten. In zwei Fällen wurden die Nietenköpfe mit einer Messingschicht behandelt (Nr. 4 und 6). Bei offensichtlich einem Fall von Burg Přimda (Nr. 1) könnte die Oberfläche des Nietenkopfes mit Zinn überzogen worden sein. Im Falle der Oberflächenbehandlung der Nieten bei den Lamellen Nr. 4 und 6 von Burg Landštejn wurden deren Köpfe zunächst mit einer Bronzeschicht und anschließend dann mit einer Messingschicht überzogen.

Bei Lamellen mit erhaltenem Metallkern war eine beträchtliche Streuung der Mikrostrukturen und damit auch des bei der Herstellung verwendeten Eingangsmaterials zu erkennen, was nicht nur die Eigenschaften der einzelnen Lamellen beeinflusste, sondern gleichzeitig auch Einfluss auf ihren Erhaltungszustand hatte. In drei Fällen bestand die Mikrostruktur ausschließlich aus grobkörnigem Ferrit (Nr. 2, 5 und 8). Gängiger war eine Mischung aus feinkörnigem und grobkörnigem Ferrit in Form von Schichten, die mit dem Herstellungsverfahren des Quellmaterials und mit dem der Lamellen selbst korrespondieren. Dieser Effekt entsteht beim Schmieden von unterschiedlicheren, bei der Herstellung der Lamellen verwendeten Materialquellen und einem mehrfachen Falten des Quellmaterials der Lamellen. Zu einer Verfeinerung der Mikrostruktur kommt es in einigen Fällen auch in der Umgebung von Einschlüssen, wenn es zum Anlegieren des Materials mit erwünschten Elementen wie z.B. Si kommt (Nr. 3, 9, 10, 11 und Nr. 13 von Burg Landštejn). In drei Fällen wurde eine Ferrit-Perlit-Mikrostruktur festgestellt, die 90 \% des Massevolumens des Eisenkerns der Lamellen ausmacht (Nr. 3, 7 und Nr. 10 von Burg Landštejn). Lamelle Nr. 1 von Burg Přimda ist dann eindeutig aus zwei deutlich unterschiedlichen Materialien zusammengesetzt. Die Mikrostruktur der einen Hälfte besteht aus Martensit, und die der zweiten aus grobkörnigem Ferrit. Eine ähnliche Materialstruktur wurde bei Lamelle Nr. 6 verzeichnet, in deren Randbereichen eine martensitische Struktur beobachtet werden konnte. Bei allen untersuchten Lamellen und Nieten wurde eine beträchtliche Streuung in Größe, Form und Menge der Einschlüsse festgestellt. Die Härte der jeweiligen Lamellen unterschied sich in Abhängigkeit von ihrer Mikrostruktur und ihrem Herstellungsverfahren. Die Härte des zur Lamellenherstelung verwendeten Ferrit-Materials bewegte sich in einer Spanne von $160-176 \mathrm{HV}_{0,3}$. Der für die Nieten verwendete Ferrittstahl wies bei einer Reihe von Fällen jedoch eine größere Härte aus. Bei den vorkommenden Ferrit-Perlit-Strukturen wiesen die Lamellen eine größere Härte auf, die sich in der Spanne von 214 bis $240 \mathrm{HV}_{0,3}$ bewegte. Im Falle von Martensit erreichte die Härte einen Wert von $280 \mathrm{HV}_{0,3}$.

Die mechanischen Eigenschaften (Kraft vs. Verformung) wurden anhand eines Small Punch Testes ermittelt. Dabei handelte es sich um die Lamellen Nr. 1 von Burg Přimda, Nr. 3, 7, 8 und 9 von Burg Landštejn (Abb. 14). Ziel des Testes war es, die Kraft festzustellen, die zu einem Materialkollaps bzw. zu Materialbruch führt. Entsprechend unserer Annahme wies die ungefähr zu gleichen Teilen aus zwei Materialien bestehende Lamelle Nr. 1 (Taf. 1, Abb. 1) die höchste Widerstandsfähigkeit auf. Das Material besteht im oberen Teil aus Martensitnadeln mit relativ niedrigem Einschlussgehalt und aus grobkörnigem Ferrit mit einem geringen Anteil an Einschlüssen. Diese Lamelle hielt bis zu einer Krafteinwirkung von 1380 N stand. Die Härte der martensitischen Lamellenteile erreichte einen Wert von $440 \mathrm{HV}_{0,3}$, der ferritische Teil dann den Wert $185 \mathrm{HV}_{0,3}$. Die zweithöchste Bruchfestigkeit weist entsprechend dem Grafikbild (Abb. 14) Lamelle Nr. 3 von Burg Landštejn auf (Taf. 1, Abb. 3), deren Mikrostruktur aus einem Mittel- 
streifen mit Ferrit-Perlit-Struktur und aus Rändern aus grobkörnigem Ferrit mit allgemein höherem Einschlussgehalt besteht. Diese Lamelle hielt bis zu einer Krafteinwirkung von $1200 \mathrm{~N}$ stand. Die Härte der Lamelle schwankte in verschiedenen Bereiches ihres Kerns zwischen einer Spanne von 214-240 $\mathrm{HV}_{0,3}$. Lamelle Nr. 7 von derselben Fundstelle (Taf. 1, Abb. 7) besteht aus Ferrit-Perlit-Stahl mit an den Perliträndern ausgeschiedenem Ferrit. Die Lamelle enthielt an der metallographischen Schliffstelle einige längliche Einschlüsse. Die ausgewertete Probe hielt bis zu einer Krafteinwirkung von 1030 N stand. Die gemessene Härte des verwendeten Materials erreichte einen Wert von $282 \mathrm{HV}_{0,3}$. Die aus der ebenfalls von Burg Landštejn stammenden, aus grobkörnigem Ferrit mit großen Einschlüssen hergestellten Lamelle Nr. 8 (Taf. 1, Abb. 8) entnommene Probe hielt bis zu einer Krafteinwirkung von $742 \mathrm{~N}$ stand. Die gemessene Härte des verwendeten Materials erreichte einen Wert von $176 \mathrm{HV}_{0,3}$. Die geringste Widerstandskraft gegen Durchdrücken wies die von der auf Burg Landštejn gefundenen, aus feinkörnigem und grobkörnigem Ferrit hergestellten Lamelle Nr. 9 (Taf. 2, Abb. 9) entnommene Probe auf. Zur Zerstörung des verwendeten Materials kam es bei einer Krafteinwirkung von 359 N. Die gemessene Härte der Lamelle erreichte einen Wert von $180 \mathrm{HV}_{0,3}$. Den höchsten Verformungsgrad des zur Herstellung der ausgewerteten Lamellen verwendeten Materials wurde bei der von aus Ferrit-Perlit-Stahl mit einer Härte von $282 \mathrm{HV}_{0,3}$ bestehenden Lamelle Nr. 7 (Taf. 1, Abb. 7) entnommenen Probe verzeichnet.

PhDr. Josef Hložek, Ph.D., Katedra archeologie Filozofické fakulty Západočeské univerzity v Plzni, Sedláčkova 15, 30614 Plzeň, Česká republika, hlozek@kar.zcu.cz

Ing. Jarmila Savková, Ph.D., Nové technologie - výzkumné centrum Západočeské univerzity v Plzni, Univerzitní 8, 30614 Plzeň, Česká republika, savkova.jarmila@atlas.cz

Ing. Josef Volák, Ph.D., Regionální technologický institut Fakulty strojní Západočeské univerzity v Plzni, Univerzitní 22, 30614 Plzeň, Česká republika,volak@rti.zcu.cz 
